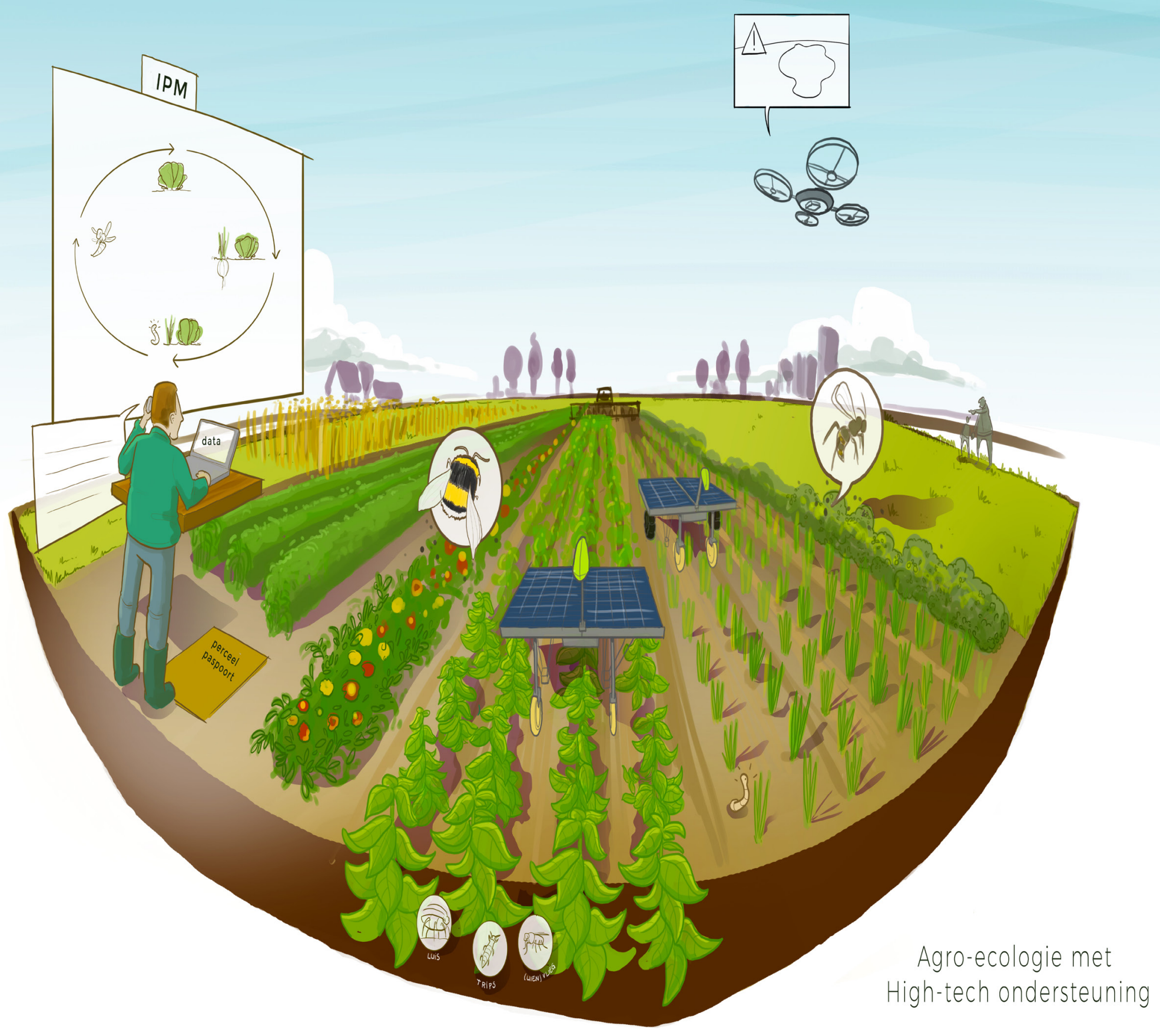

Gezonde, robuuste bodem en teeltsystemen gebaseerd op agroecologie en zonder schadelijke emissies naar grond- en oppervlaktewater

Marleen Riemens met input van Marcia Stienezen, Willem Jan de Kogel, Janjo de Haan, Bert Lotz, Wijnand Sukkel, Anne van Doorn, Olga Scholten 


\section{Gezonde, robuuste bodem en teeltsystemen gebaseerd op agro-ecologie en zonder schadelijke emissies naar grond- en oppervlaktewater}

Marleen Riemens met input van Marcia Stienezen, Willem Jan de Kogel, Janjo de Haan, Bert Lotz, Wijnand Sukkel, Anne van Doorn, Olga Scholten

Dit onderzoek is in opdracht van Het Ministerie van LNV uitgevoerd door de Stichting Wageningen Research (WR), business unit Open Teelten.

WR is een onderdeel van Wageningen University \& Research, samenwerkingsverband tussen Wageningen University en de Stichting Wageningen Research.

Wageningen, december 2019

Rapport WPR-814 
Gezonde, robuuste bodem en teeltsystemen gebaseerd op agro-ecologie en zonder schadelijke emissies naar grond- en oppervlaktewater; . Wageningen Research, Rapport WPR-814.

Dit rapport is gratis te downloaden op https://doi.org/ 10.18174/508373

\section{Aanleiding: missie gedreven innovatie}

Het Ministerie van LNV heeft zes missies gedefinieerd om de maatschappelijke opgaven voor het thema Landbouw, Water, Voedsel aan te pakken. Eén daarvan is Gezonde, robuuste bodem en teeltsystemen gebaseerd op agro-ecologie en zonder emissies naar grond- en oppervlaktewater. De missies geven ambities voor kennis en innovatie: zij moeten prikkelen tot ambitieus onderzoek en doorslaggevende innovaties. Het Ministerie wil een goed beeld te krijgen van: het voor de missie noodzakelijke onderzoek, van lopende initiatieven, van betrokken partijen, en van beschikbare kennis. De maatschappelijke relevantie van dit onderwerp is groot, wat blijkt uit de recentelijk gepubliceerde "Toekomstvisie Gewasbescherming 2030 naar weerbare planten en teeltsystemen", EU Kaderrichtlijn Water, het Deltaplan Biodiversiteit en de door de sectoren geformuleerde ambities en actieplannen op dit onderwerp (Actieplan Plantgezondheid)..

(C) 2019 Wageningen, Stichting Wageningen Research, Wageningen Plant Research, Business unit Open Teelten, Postbus 16, 6700 AA Wageningen; www.wur.nl/Open Teelten

KvK: 09098104 te Arnhem

VAT NL no. 8113.83.696.B07

Stichting Wageningen Research. Alle rechten voorbehouden. Niets uit deze uitgave mag worden verveelvoudigd, opgeslagen in een geautomatiseerd gegevensbestand, of openbaar gemaakt, in enige vorm of op enige wijze, hetzij elektronisch, mechanisch, door fotokopieën, opnamen of enige andere manier zonder voorafgaande schriftelijke toestemming van Stichting Wageningen Research.

Stichting Wageningen Research is niet aansprakelijk voor eventuele schadelijke gevolgen die kunnen ontstaan bij gebruik van gegevens uit deze uitgave.

Rapport WPR-814 


\section{Inhoud}

1

$\begin{array}{ll}\text { Maatschappelijke opgave } & 7\end{array}$

2

Kennis en innovatieopgaven $\quad 11$

2.1 Slim inrichten van weerbare plantaardige productiesystemen, waaronder 11

2.2 Slim bijsturen van plantaardige productie; 11

$3 \quad$ Lopend onderzoek $\quad 13$

$\begin{array}{llr}\text { Witte vlekken } & 21\end{array}$

$\begin{array}{llr}5 & \text { Mogelijke consortia en financiering } & 27\end{array}$

$\begin{array}{llr}6 & \text { Programmeringsadvies } & 29\end{array}$ 



\section{Doel van deze studie}

Deze programmeringsstudie richt zich inhoudelijk op gezonde, robuuste bodem en teeltsystemen gebaseerd op agro-ecologie en zonder emissies naar grond- en oppervlaktewater. Binnen de topsectoren T\&U en A\&F lopen gerelateerde projecten, bijvoorbeeld op het gebied van bodem en plantgezondheid. Deze programmeringsstudie heeft tot doel een integrale visie te ontwikkelen waarbij het lopende onderzoek gekaderd en met elkaar verbonden wordt, een link naar de topsector Water gelegd wordt en nieuwe ontwikkelpunten geïdentificeerd worden

\section{Werkwijze}

Binnen deze programmeringsstudie zijn de volgende activiteiten uitgevoerd: een omgevingsscan, een workshop en het opstellen van een programmeringsadvies. Hieronder volgt een toelichting op de aanpak van deze activiteiten.

1. Omgevingsscan

a. Inventarisatie van de maatschappelijke opgave. De omgevingsscan is uitgevoerd om de maatschappelijke opgave t.a.v. Gezonde, robuuste bodem en teeltsystemen gebaseerd op agro-ecologie en zonder emissies naar grond- en oppervlaktewater in de context te plaatsen. Verschillende sectorpartners, het ministerie LNV, ministerie van $L$ en W, en ngo's hebben op relevante (deel)onderwerpen visies, actieplannen en ambities geformuleerd. Vertegenwoordigers van deze organisaties zijn bevraagd en hebben relevante brondocumenten aangeleverd. Op basis hiervan is de maatschappelijke opgave geformuleerd, evenals hieruit voortvloeiende kennis en innovatie opgaven (zie verderop punt 1 Maatschappelijke opgave).

b. Inventarisatie van de lopende initiatieven.

Op basis van de onder a opgestelde kennis en innovatie opgaven is een enquête uitgegaan naar kennisinstellingen om een overzicht te krijgen van lopende initiatieven gericht op deze kennis en innovatie opgaven (zie verder op punt 2 Lopend onderzoek). Er is een inventarisatie gemaakt van lopende initiatieven in fundamentele onderzoeksprojecten (TRL1-3), in toegepast onderzoek in ontwikkelingsprojecten (TRL4-6), middels participerend onderzoek en demonstratie (TRL 7-9). Deze activiteiten worden ondersteund door investeringen, regelgeving, kennisverspreiding, netwerken en subsidies om te komen tot implementatie.

c. Identificatie van witte vlekken: missende kennis en innovatie opgaven identificeren. De inventarisatie van de lopende initiatieven heeft een overzicht opgeleverd van de voor de missie relevante kennis en innovatie opgaven die nog niet (voldoende) worden aangepakt. Dit levert een overzicht op van nieuwe ontwikkelpunten (zie punt 3 witte vlekken).

2. Interactieve workshop op 9 mei 2019 met kennisinstellingen (niet alleen WUR), overheden, landbouwbedrijfsleven, ketenpartijen, en betrokkenen bij het Deltaplan Biodiversiteit. De eerste versie van de omgevingsscan is getoetst in de workshop en aangepast naar aanleiding van de resultaten van de workshop. Tevens is in kaart gebracht wat het perspectief is om de witte vlekken in het onderzoek via een publiek-private aanpak in te vullen (punt 4 mogelijke consortia en financiering).

3. Op basis van de resultaten van de workshop en verdiepende gesprekken is een programmeringsadvies opgesteld (zie verderop punt 5 programmeringsadvies). 


\section{Maatschappelijke opgave}

\section{Missie A2 Gezonde, robuuste bodem en teeltsystemen gebaseerd op agro-ecologie en zonder schadelijke emissies naar grond- en oppervlaktewater:}

In 2030 is in de land- en tuinbouw het gebruik van grondstoffen en hulpstoffen substantieel verminderd en worden alle eind- en restproducten zo hoog mogelijk verwaard. De schadelijke emissies van gewasbeschermingsmiddelen en nutriënten naar de omgeving zijn tot nagenoeg nul gereduceerd. De productiesystemen dragen bij aan de reductie van broeikasgasemissies. Ecologische omstandigheden en processen vormen het vertrekpunt voor voedselproductie waardoor biodiversiteit zich herstelt en de land- en tuinbouw robuust en veerkrachtiger wordt.

De Nederlandse land- en tuinbouw is wereldwijd bekend om zijn kwalitatief hoogwaardige producten en levert een belangrijke bijdrage aan onze economie. Tegelijk staat Nederland voor grote maatschappelijke uitdagingen:

- Er zijn maatschappelijke zorgen over de mogelijke effecten van emissies van gewasbeschermingsmiddelen en nutriënten naar mens en milieu. De stand van de biodiversiteit in Nederland heeft volop publieke aandacht. Tegelijkertijd leiden nieuwe wetenschappelijke inzichten tot strengere beoordelingscriteria van werkzame stoffen en een smaller pakket beschikbare gewasbeschermingsmiddelen. Voor telers wordt een afdoende bescherming van hun gewassen steeds complexer.

- Nederland heeft zich verbonden aan internationale Sustainable Development Goals van de Verenigde naties, waaronder de aanpak van klimaatverandering en herstel en behoud van biodiversiteit. Nederland heeft zich verbonden aan het internationale klimaatakkoord. Daarin is afgesproken om de broeikasgasemissies, ook uit de landbouw, sterk terug te dringen en koolstof vast te leggen o.a. in landbouwbodems.

- Het belang van voldoende water van goede kwaliteit: Nederland zet in op het verbeteren van de waterkwaliteit van grondwater en oppervlakte water voor verbetering natuur en drinkwaterkwaliteit;

- Beter omgaan met schaarse hulpbronnen als energie, water en fosfaat. Energiegebruik is ook gekoppeld aan het beperken van broeikasgasemissies. Efficiënter omgaan met water gaat om meer water vasthouden in landbouwbodems en efficiënte irrigatietechnieken. Gebruik maken van gewassen en rassen met minder waterbehoefte en een hogere nutriëntenefficiëntie;

- Bijdragen in het voorkomen van wateroverlast (zowel teveel als te weinig water o.a. voortkomend uit klimaatverandering) door meer water vasthouden in landbouwbodems en robuustere gewassen;

- Voldoende en gezond voedsel (food), voer (feed) en non-food producten voor de NL markt en daarbuiten. 
Nederlandse land- en tuinbouw in 2030

In 2030 bestaat de land- en tuinbouw in Nederland uit een duurzame, economisch volhoudbare plantaardige productie met weerbare planten en teeltsystemen op een gezonde bodem, waardoor ziekten en plagen veel minder kansen krijgen en het gebruik van externe inputs (gewasbeschermingsmiddelen en nutriënten) zo veel mogelijk kan worden voorkomen. Dit vraagt om een uitbreiding van denken uit productie maximalisatie op basis van inputs (in de voorliggende studie: gewasbeschermingsmiddelen en meststoffen) met het denken vanuit weerbare planten en teeltsystemen die een bijdrage leveren aan onze leefomgeving waarbij productie van voldoende en gezond voedsel (food), voer (feed) en non-food producten voor de NL markt en daarbuiten, voorop staat.
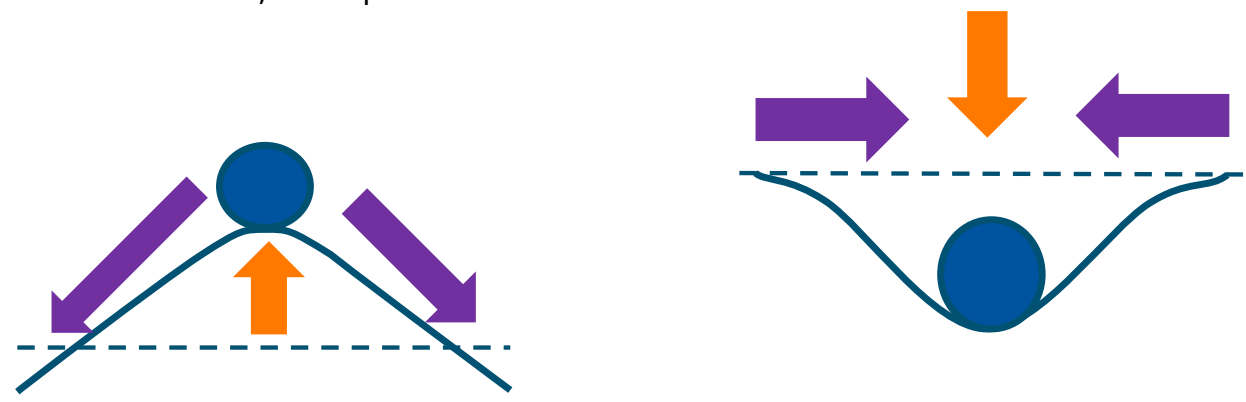

Van productiemaximalisatie op basis van inputs (links), uitbreiding met denken in weerbare, robuuste agro-ecologische productiesystemen (rechts). Naar: Haan et al 2008, Acta horticulturae 852(852)en Erisman et al., 2016. AIMS Agriculture and Food Volume 1, Issue 2, 157-174

De slimme teeltsystemen gestoeld op ecologische processen benutten en voeden de gezonde bodem en geven ziekten en plagen veel minder kansen. De nieuwe teeltsystemen maken optimaal gebruik van de (bio)diversiteit door intelligente bouwplannen, nieuwe gewasconfiguraties en -combinaties (waaronder stroken- en mengteelten), en het gebruik van (natuurlijke) vegetatie. Hierdoor dragen ze bij aan het herstel van de biodiversiteit en zorgen voor een natuurlijke regulatie van ziekten, plagen en onkruiden (Functionele Agro Biodiversiteit). Landbouw en natuur zijn met elkaar verbonden, evenals de huidige sectoren akkerbouw, veehouderij en tuinbouw. Door gebruik te maken van de ecologische processen en als gevolg van regio- en grondsoort specifieke condities ontstaan er specifieke gebiedsgerichte teeltsystemen.

Een gezonde bodem (substraat) vormt de basis van robuuste teeltsystemen. Een gezonde bodem draagt bij aan goede gewasopbrengsten, een hogere biodiversiteit en weerbaarheid van de systemen tegen (a)biotische stress, zoals extreme droogte, wateroverlast en ziekten en plagen. Daar waar gewasbeschermingsmiddelen worden gebruikt, is dit conform de principes van geïntegreerde gewasbescherming, nagenoeg zonder schadelijke emissies naar het milieu en nagenoeg zonder residuen. De inzet van resistente en tolerante rassen in combinatie met het gebruik van biologische plaagbestrijders, biostimulanten, mechanische technieken en inzet van laag risico middelen zijn belangrijke principes van geïntegreerde gewasbescherming. Ziekten, plagen en onkruiden worden net als gewasgezondheid via monitorings- en detectietechnieken waargenomen. Deze gegevens worden via (Big) Data systemen verwerkt tot praktische, handzame informatie voor de teler en adviseur waardoor deze kosteneffectief kunnen bijsturen. Gewasbeschermingsmiddelen en nutrienten worden via precisietechnieken toegepast. Hiermee wordt tegelijkertijd een blijvend economisch perspectief voor de land- en tuinbouw gerealiseerd. 


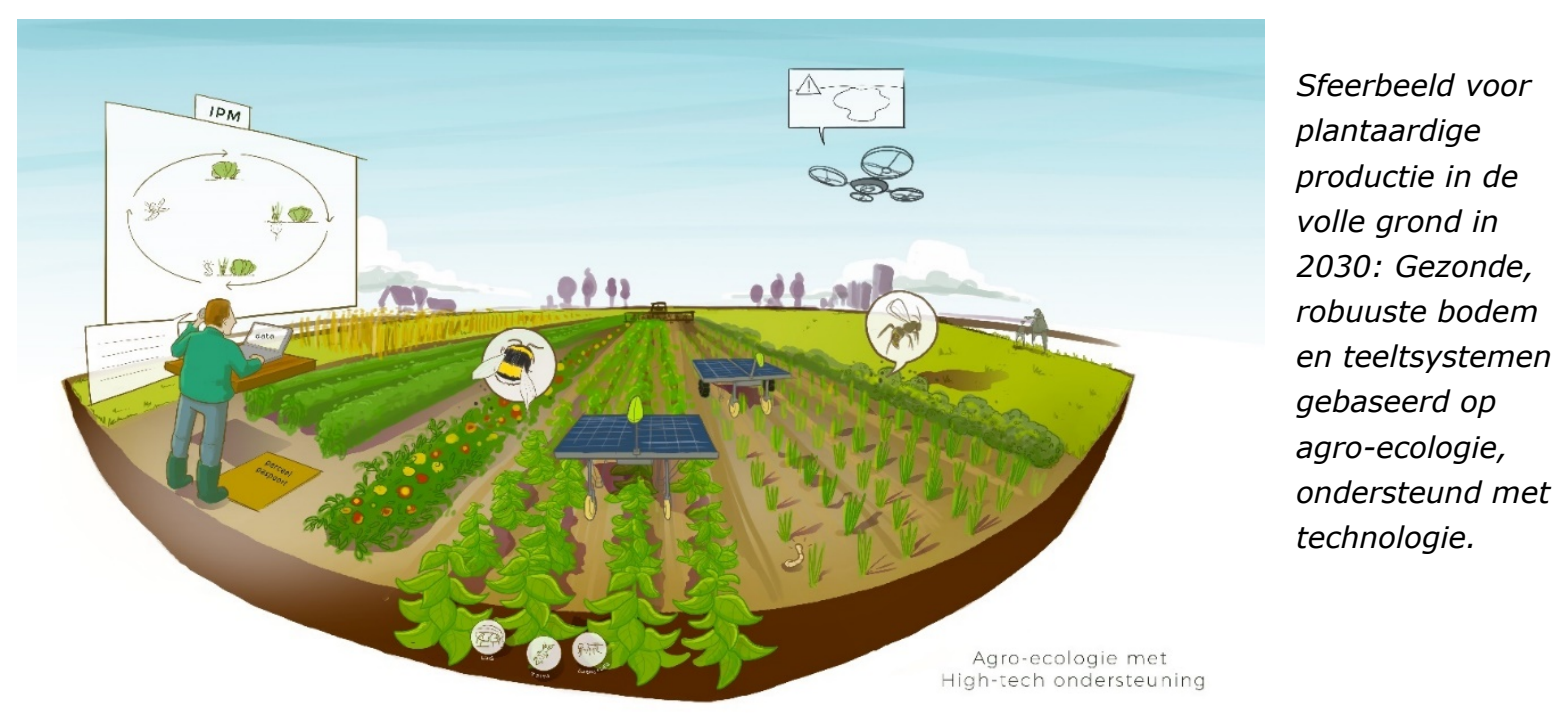

De realisatie van dit doel vraagt tevens de realisatie van een aantal subdoelen:

- In 2030 zijn alle Nederlandse bodems duurzaam beheerd;

- In 2030 is Nederland toonaangevend op het gebied van duurzame gewasbescherming en is dit het business model waarmee Nederlandse telers en partijen in de keten zich onderscheiden op de internationale markt. De teeltsystemen zijn zo ingericht dat niet alleen de plant, maar ook de omgeving gezond blijft;

- In 2050 wordt geteeld in genetisch diverse en agro- biodiverse productiesystemen;

- In 2030 zijn teeltsystemen klimaatadaptief (bestand tegen grote (a)biotische schommelingen als gevolg van klimaatverandering);

- In 2030 is de teelt in de glastuinbouw volledig circulair en gezond; 


\section{Kennis en innovatieopgaven}

De land en tuinbouw maakt in 2030 gebruik van robuuste teeltsystemen met een efficiënt gebruik van grondstoffen, een betere benutting van nutriënten, zonder belasting van grond en oppervlakte water, gezonde bodems en draagt bij aan een natuurinclusieve landbouw. Er is ruimte voor regionale en

lokale productie van eiwitrijke gewassen waarbij over de sectoren heen wordt samengewerkt.

Bij de ontwikkeling van weerbare plantaardige productiesystemen zijn twee stappen te volgen: het slim inrichten van het systeem, en het slim bijsturen van het systeem:

\subsection{Slim inrichten van weerbare plantaardige productiesystemen, waaronder}

a) Het ontwerp van het totale weerbare, robuuste systeem, door slim benutten van bodem, robuuste rassen, gewasdiversiteit in ruimte en tijd (mengteelt, rotatie), functionele agrobiodiversiteit, gewasbeschermingstechnieken, hygiëne maatregelen, fytosanitatie en bemesting, rekening houdend met plaatselijke omstandigheden. Weerbare systemen zijn in 2030 ook klimaatadaptief.

b) Duurzaam bodem- en waterbeheer;

c) Robuuste weerbare rassen ${ }^{1}$;

- Resistente en tolerante gewassen tegen biotische aspecten als ziekten, plagen onkruiden;

- Weerbaar tegen fysische extremen en met optimale benutting van grondstoffen; Resource use efficiënte gewassen (gereduceerde waterbehoefte, zouttolerant, verminderde nutriënten behoefte, etc)

d) Functionele agrobiodiversiteit ${ }^{2}$ : ondergrondse, bovengrondse biodiversiteit en interacties daartussen. Van bodembiodiversiteit, via bovengrondse biodiversiteit op micro, macro, plant, gewas, bedrijf en regio niveau.

e) Het ondersteunen van samenwerking tussen verschillende sectoren (akkerbouw, bollen, glastuinbouw, bomen, (grondgebonden) veehouderij) op het gebied van o.a. reststromen, bemesting, landgebruik, zowel regionaal als nationaal met inachtneming van de internationale setting van de Nederlandse land- en tuinbouw

\subsection{Slim bijsturen van plantaardige producties;}

a. Monitoring- en detectie systemen t.b.v. waarnemen ziekten, plagen, onkruiden en gewasgezondheid voor nauwkeurig bijsturen gewasbescherming en nutriënten;

b. Nieuwe gewasbescherming strategieën met precieze inzet van biologische (zowel micro als macro), niet chemische en chemische maatregelen (laag risico middelen);

c. Nieuwe bemestingsstrategieën met inzet van precisiebemesting, recirculatie en slim beheer en inzet van organische stof;

\footnotetext{
${ }^{1} \mathrm{Er}$ is een aparte Programmeringsstudie sleuteltechnologieën: biotechnologie en veredeling waarin de technieken die nodig zijn om tot robuuste plantaardige rassen te kunnen komen staan beschreven.

${ }^{2} \mathrm{Er}$ is een aparte Programmeringsstudie Herstel en benutten biodiversiteit. In die studie ligt de nadruk op herstel van biodiversiteit, in deze studie betreft het de bijdrage van functionele agrobiodiversiteit aan de primaire productie.

${ }^{3} \mathrm{Er}$ is een aparte Programmeringsstudie sleuteltechnologie Slimme technologie / high tech waarin de technieken die nodig zijn om te komen tot sensoren en robotisering tbv precisielandbouw beschreven staan.
} 


\section{Lopend onderzoek}

Voor een beschrijving van het lopende onderzoek op het gebied van Gezonde, robuuste bodem en teeltsystemen gebaseerd op agro-ecologie en zonder schadelijke emissies naar grond- en oppervlaktewater zijn ongeveer 75 TKI-projecten in beeld gebracht. Dit betreft voornamelijk PPS-en, zowel lopende als recent afgelopen PPS-en, die tijdens de verschillende calls van de Topsector T\&U en A\&F zijn gehonoreerd. Daarnaast zijn ook de EU-cofinancieringsprojecten en de NWO-projecten met deelfinanciering voor WR-capaciteit meegenomen. Daarnaast zijn relevante POP projecten opgenomen. Op basis van deze informatie is een overzicht gemaakt van lopende onderzoeksprojecten per deelprogramma op TRL niveau. In onderstaande tabel wordt per TRL niveau een overzicht gegeven van lopend onderzoek voor elk van de bovengenoemde kennis en innovatie opgaven.

Tabel 1 een overzicht van lopend onderzoek voor elk van de bovengenoemde kennis en innovatie opgaven

\begin{tabular}{|c|c|c|c|c|}
\hline Onderwerp & $\begin{array}{l}\text { Onderzoeksfase } \\
\text { TRL 1-3 } \\
\text { (NWO, KNAW, EU, } \\
\text { Kennis-basis, } \\
\text { strategische } \\
\text { middelen etc.) }\end{array}$ & $\begin{array}{l}\text { Ontwikkelfase TRL 4-6 } \\
\text { (toegepast onderzoek, } \\
\text { beleidsondersteunend } \\
\text { onderzoek) }\end{array}$ & $\begin{array}{l}\text { Demonstratiefase TRL 7- } \\
9 \\
\text { (MIT, POP, fieldlabs, } \\
\text { etc.) }\end{array}$ & $\begin{array}{l}\text { Implementatiefase } \\
\text { (subsidies, investeringen, } \\
\text { regelgeving, kennisverspreiding, } \\
\text { netwerken, campagnes etc.) }\end{array}$ \\
\hline \multicolumn{5}{|c|}{ Deelprogramma 1: Slim inrichten van weerbare plantaardige productie systemen } \\
\hline $\begin{array}{l}\text { A Het ontwerp van } \\
\text { het totale weerbare, } \\
\text { robuuste, } \\
\text { klimaatadaptieve } \\
\text { systeem, door slim } \\
\text { benutten van } \\
\text { bodem, robuuste } \\
\text { rassen, functionele } \\
\text { agrobiodiversiteit, } \\
\text { gewasdiversiteit in } \\
\text { ruimte en tijd, } \\
\text { gewasbescherming, } \\
\text { en bemesting, } \\
\text { rekening houdend } \\
\text { met plaatselijke } \\
\text { omstandigheden. }\end{array}$ & $\begin{array}{l}\text { AF-EU-17028 | } \\
\text { Agrilink (2017- } \\
\text { 2021) } \\
\text { AF-EU-17035 | } \\
\text { Plaid (2017-2019) } \\
\text { EU } 18019 \\
\text { Diverimpacts } \\
\text { (2018-2022) } \\
\text { KB-34-008-002 } \\
\text { Living labs (2019) }\end{array}$ & $\begin{array}{l}\text { BO-43-011.06 } \\
\text { Verduurzamen } \\
\text { Plantaardige } \\
\text { productieketens } \\
\text { AF- Amazing Grazing } \\
(2016-2019)\end{array}$ & $\begin{array}{l}\text { MIT-15005 I } \\
\text { Voedselproductie op } \\
\text { verzilte bodem (2016- } \\
\text { 2017) } \\
\text { MITAF-14086 I } \\
\text { Introductie van plant- } \\
\text { specifieke resources- } \\
\text { huishouding (2016-2017) } \\
\text { POP Drenthe: Schone } \\
\text { teelt op basis van } \\
\text { druppelirrigatie (2018- } \\
\text { 2021) } \\
\text { POP3 Groningen } \\
\text { Vergroening } \\
\text { Veenkoloniën } \\
\text { POP3 Friesland: Stikstof } \\
\text { Telen, vlinderbloemigen } \\
\text { als basis voor een } \\
\text { natuurinclusieve } \\
\text { akkerbouw (2018-2020) } \\
\text { POP3 Flevoland } \\
\text { Flevoland Innovatieland } \\
\text { (2018-2021) }\end{array}$ & $\begin{array}{l}\text { EU } 18028 \text { Nefertiti (2018-2021) } \\
\text { https://vruchtbarekringloopachterho } \\
\text { ek.nl/over-vka/ }\end{array}$ \\
\hline $\begin{array}{l}\text { B Duurzaam } \\
\text { bodembeheer }\end{array}$ & $\begin{array}{l}\text { NWO-15001 | } \\
\text { Harnessing the soil } \\
\text { microbiome for } \\
\text { improved stress } \\
\text { tolerance in crop } \\
\text { plants (2016-2021) } \\
\text { NWO-15005 | Vital } \\
\text { soils for sustainable } \\
\text { intensification of } \\
\text { agriculture (2016- } \\
\text { 2020) } \\
\text { NWO-14002 | } \\
\text { Unravelling the } \\
\text { mechanisms } \\
\text { underlying health } \\
\text { and productivity }\end{array}$ & $\begin{array}{l}\text { AF-15261 | Sturen op } \\
\text { bodemweerbaarheid door } \\
\text { toediening van organische } \\
\text { materialen (2016-2019) } \\
\text { AF-15252 | } \\
\text { Systeemoplossing ziekten } \\
\text { en plagen in } \\
\text { bioglasgroenten (2016- } \\
\text { 2019) } \\
\text { AF-16064 | Beter } \\
\text { bodembeheer (2017-2020) } \\
\text { AF-17065 I Belang van } \\
\text { vastlegging van koolstof in } \\
\text { de bodem voor mitigatie }\end{array}$ & $\begin{array}{l}\text { MTRLA-16118 | } \\
\text { Ontwikkeling biologische } \\
\text { oplossing ter bestrijding } \\
\text { van vrijlevende- en plant } \\
\text { parasitaire aaltjes in de } \\
\text { akkerbouw (2016-2018) } \\
\text { MTHLA-16260 | } \\
\text { Haalbaarheidsstudie } \\
\text { biologische } \\
\text { bestrijdingsstrategie } \\
\text { (2016-2017) } \\
\text { POP3 Drenthe: MAXUS } \\
\text { POP3 Drenthe: Compost } \\
\text { composities (2018-2021) } \\
\text { POP3 Flevoland }\end{array}$ & $\begin{array}{l}\text { Europees Landbouwfonds voor } \\
\text { Plattelandsontwikkeling (ELFPO) } \\
\text { http://www.grondigboerenmetmais. } \\
\underline{\mathrm{nl} /} \\
\text { Bodemcoalitie: ontwikkeling } \\
\text { Bodemlabel }\end{array}$ \\
\hline
\end{tabular}




\begin{tabular}{|c|c|c|c|c|}
\hline & $\begin{array}{l}\text { promoting } \\
\text { agricultural } \\
\text { practices by fine- } \\
\text { mapping } \\
\text { rhizosphere } \\
\text { communities } \\
\text { (2015-2019) } \\
\text { NWO-14007 | } \\
\text { Clever Cover } \\
\text { Cropping: } \\
\text { Synergistic } \\
\text { Mixtures for } \\
\text { Sustainable Soils } \\
\text { (2015-2020) } \\
\text { NWO-14009 | } \\
\text { SQUASH: a Soil } \\
\text { Quality Universally } \\
\text { Applicable Soil } \\
\text { Health assessment } \\
\text { system (2016-2020) } \\
\text { AF-EU-16011 | } \\
\text { LANDMARK (2016- } \\
\text { 2018) } \\
\text { AF-EU-15040 | } \\
\text { iSQUAPER: } \\
\text { Interactive Soil } \\
\text { Quality Assessment } \\
\text { in Europe and } \\
\text { China (2015-2019) } \\
\text { KB-34-008-001 Soil } \\
\text { biology as basic } \\
\text { element for } \\
\text { resilient cropping } \\
\text { systems and C- } \\
\text { sequestration } \\
\text { (2019) } \\
\text { KB-34-008-005 } \\
\text { SOILCARE (2019) } \\
\text { KB34-005-001 1-2a- } \\
\text { 1 Peatlands in the } \\
\text { new circular and } \\
\text { climate positive } \\
\text { production systems }\end{array}$ & $\begin{array}{l}\text { van broeikasgassen (2017- } \\
2018) \\
\text { AF-17003 |Effect van de } \\
\text { bodem op weerbaarheid } \\
\text { van aardappelknollen } \\
\text { tegen biotische stress } \\
\text { (2018-2021) } \\
\text { AF-18085 | TU18150 } \\
\text { Groenbemesters in de } \\
\text { praktijk (2019-2022) } \\
\text { AF-18032 | Slimme } \\
\text { bouwplannen voor } \\
\text { bodemgezondheid (2019- } \\
\text { 2022) } \\
\text { AF 16190 SMARAGD } \\
\text { (2018-2021) } \\
\text { BO-43-012.02-001 } \\
\text { Langjarige fosfaatproeven } \\
\text { BO-53-002 Slim } \\
\text { Landgebruik }\end{array}$ & $\begin{array}{l}\text { Voorjaarsploegen } \\
\text { Winterbedekkende } \\
\text { Groenbemesters (2018- } \\
\text { 2021) } \\
\text { POP3 Flevoland } \\
\text { Lasting Fields in de } \\
\text { Praktijk (2018-2021) } \\
\text { POP3 NoordHolland: } \\
\text { BRIzonder: bodem } \\
\text { resetten \& inundatie } \\
\text { POP3 Gelderland } \\
\text { Verminderen } \\
\text { ondergrond-verdichting } \\
\text { (2018-2020) } \\
\text { POP3 Zuid Holland } \\
\text { Hoeksche Waard Rond } \\
\text { POP3 Zuid Holland } \\
\text { Samen innoveren voor } \\
\text { groene groei }\end{array}$ & \\
\hline $\begin{array}{l}\text { C Robuuste Rassen } \\
\text { Deze lijn sluit aan } \\
\text { bij de MMIP } \\
\text { sleuteltechnologie } \\
\text { uitgangsmaterialen } \\
\text { en veredeling }\end{array}$ & $\begin{array}{l}\text { NWO-15001 I } \\
\text { Regulation of } \\
\text { glandular } \\
\text { trichome } \\
\text { formation in } \\
\text { tomato (2016- } \\
2021 \text { ) } \\
\text { NWO-15003 I } \\
\text { Unravelling Tsw- } \\
\text { mediated } \\
\text { resistance and } \\
\text { the interplay } \\
\text { with the innate } \\
\text { immunity } \\
\text { modulator NSs of } \\
\text { Tomato spotted } \\
\text { wilt virus, a } \\
\text { plant-infecting }\end{array}$ & $\begin{array}{l}\text { TU18002 } \\
\text { Fijnkartering tulp } \\
\text { resistenties en } \\
\text { ontwikkeling nieuwe } \\
\text { veredelingsmethoden } \\
\text { (2019-) } \\
\text { TU18003 Lasting } \\
\text { Beauty/SciFi (2019-) } \\
\text { TU18015 } \\
\text { Counteracting } \\
\text { Botrytis and } \\
\text { Alternaria infection } \\
\text { by interfering with } \\
\text { plant susceptibility } \\
\text { genes (2019-) }\end{array}$ & $\begin{array}{l}\text { POP3 Groningen Naar } \\
\text { een rendabele } \\
\text { sojateelt in de } \\
\text { Veenkoloniën (2018- } \\
\text { 2020) } \\
\text { POP3 Groningen } \\
\text { Rassenveredeling } \\
\text { zetmeelaardappelen: } \\
\text { IDA (2016-2020) } \\
\text { POP3 Groningen } \\
\text { Ontwikkeling van } \\
\text { duurzame en } \\
\text { klimaatbestendige } \\
\text { robuuste } \\
\text { aardappelrassen door }\end{array}$ & \\
\hline
\end{tabular}




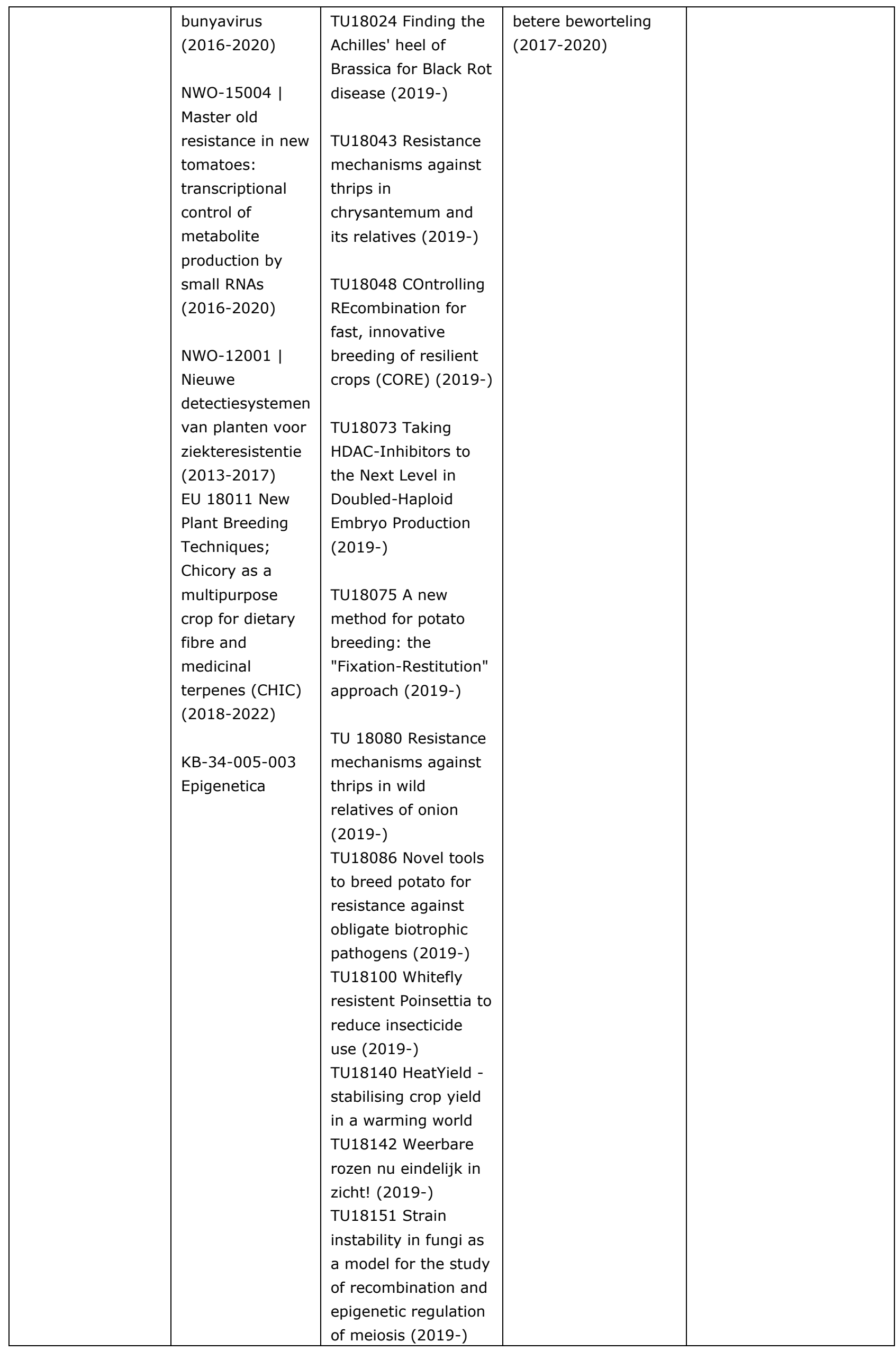




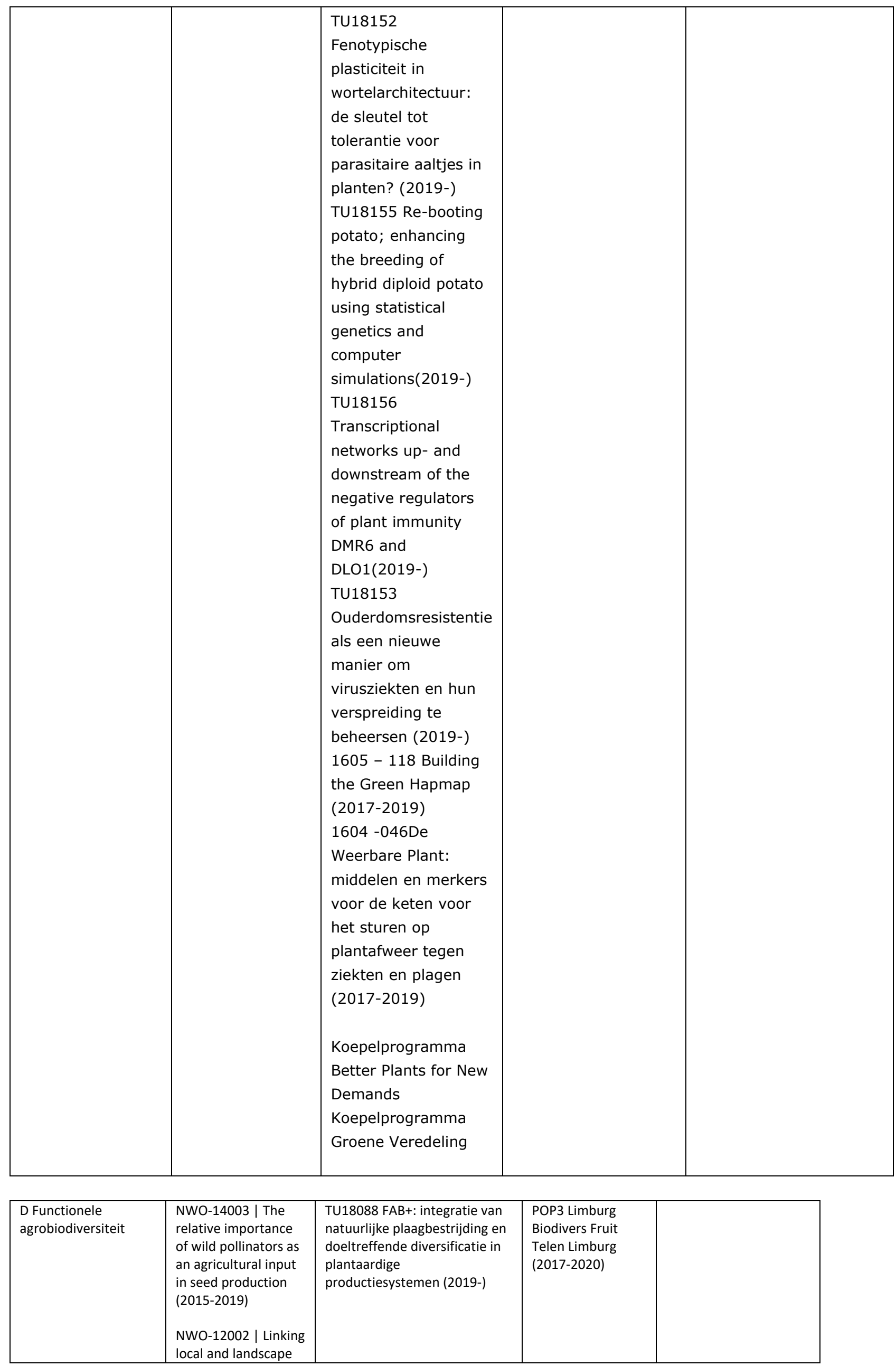




\begin{tabular}{|c|c|c|c|c|}
\hline & $\begin{array}{l}\text { scale trophic } \\
\text { interactions for } \\
\text { plant-induced } \\
\text { biological control of } \\
\text { insect pests (2013- } \\
\text { 2017) }\end{array}$ & & & \\
\hline $\begin{array}{l}\text { E Ondersteunen van } \\
\text { samenwerking tussen } \\
\text { de sectoren }\end{array}$ & $\begin{array}{l}\text { KB-21-003-001 } \\
\text { Samenwerking } \\
\text { Akkerbouw } \\
\text { Veehouderij (2015- } \\
\text { 2018) }\end{array}$ & $\begin{array}{l}\text { AF-15284 | Ruwvoerproductie } \\
\text { en bodemmanagement (2016- } \\
\text { 2019) } \\
\text { AF-17106 | Regenerative } \\
\text { Farming (2018-2022) } \\
\text { AF-17021 |Verbeteren van de } \\
\text { kringloopwijzer (2018-2021) }\end{array}$ & & \\
\hline \multicolumn{5}{|c|}{ Deelprogramma 2 Slim bijsturen van weerbare plantaardige productie systemen } \\
\hline $\begin{array}{l}\text { A Monitoring- en } \\
\text { detectie systemen } \\
\text { Deze lijn sluit aan bij } \\
\text { de MMIP } \\
\text { sleuteltechnologie } \\
\text { precisietechnieken }\end{array}$ & $\begin{array}{l}\text { AF-EU-16013 | Smart } \\
\text { AKIS (2016-2018) } \\
\text { EU 18046 VALITEST: } \\
\text { Validation of } \\
\text { diagnostic tests to } \\
\text { support plant health } \\
\text { (2018-2020) } \\
\text { EU 18032 Optima } \\
\text { (2018-2021) }\end{array}$ & 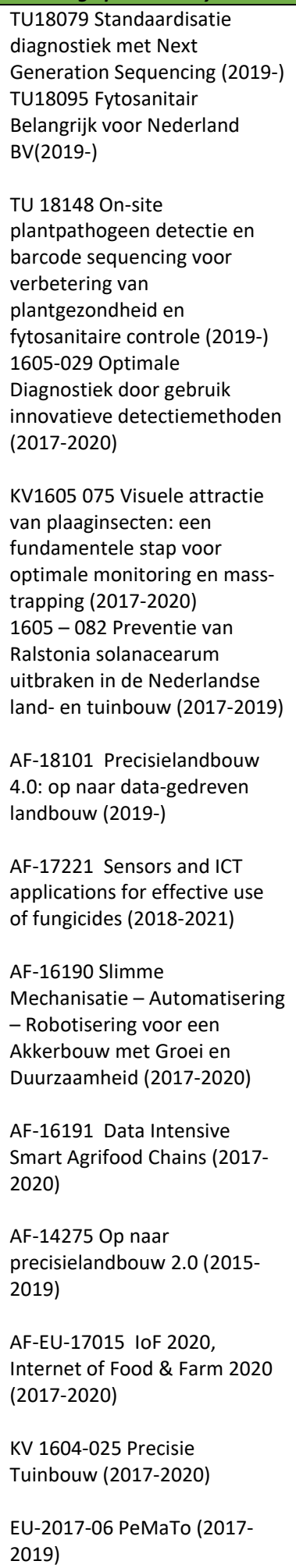 & $\begin{array}{l}\text { POP3 Gelderland } \\
\text { Voelhoorn } \\
\text { duurzaamheid } \\
\text { (2018-2019) } \\
\text { POP3 Flevoland } \\
\text { Data Boeren } \\
\text { (2018-2021) } \\
\text { AF-EU-17017 I } \\
\text { ANTARES (2017- } \\
\text { 2024) }\end{array}$ & $\begin{array}{l}\text { Nationale Proeftuin } \\
\text { Precisie Landbouw } \\
\text { (NPPL) }\end{array}$ \\
\hline
\end{tabular}




\begin{tabular}{|c|c|c|c|c|}
\hline & & $\begin{array}{l}\text { BO } 52 \text { TU-HTDT High Tech \& } \\
\text { Digitale Transformatie } \\
\text { projecten: oa HT-17222 } \\
\text { Exploitation of high-tech plant } \\
\text { phenotyping tools (2018-2021) }\end{array}$ & & \\
\hline $\begin{array}{l}\text { B Nieuwe } \\
\text { gewasbescherming } \\
\text { strategieën }\end{array}$ & $\begin{array}{l}\text { NWO-15006 | } \\
\text { Biological control of } \\
\text { the new invasive pest } \\
\text { species Spotted Wing } \\
\text { Drosophila (2016- } \\
\text { 2020) } \\
\text { NWO-15007 | } \\
\text { Boosting the efficacy } \\
\text { of biological control } \\
\text { agents of citrus } \\
\text { mealybugs through } \\
\text { olfactory } \\
\text { conditioning (2016- } \\
\text { 2020) } \\
\text { NWO-14005 | A } \\
\text { biodiversity approach } \\
\text { to develop } \\
\text { multispecies } \\
\text { microbial inoculants } \\
\text { for sustainable crop } \\
\text { protection (2015- } \\
\text { 2019) } \\
\text { AF-EU-17031 | } \\
\text { IWMPRAISE (2017- } \\
\text { 2022) }\end{array}$ & 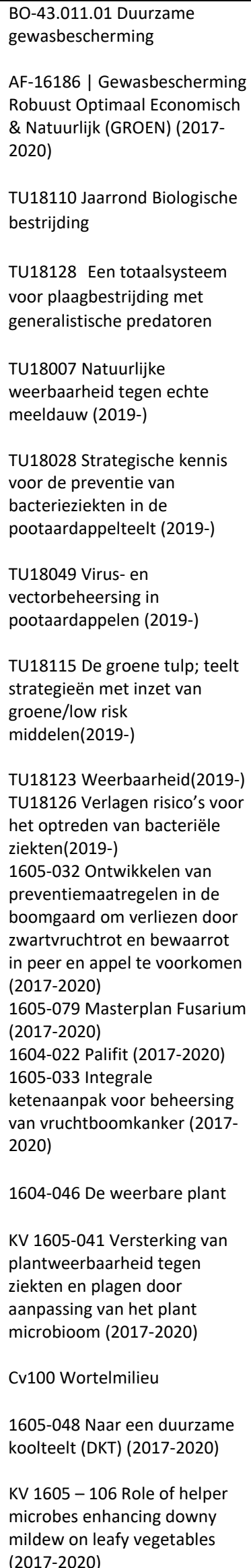 & $\begin{array}{l}\text { TU18143 Milieu } \\
\text { indicator } \\
\text { gewasbescherming } \\
\text { (2019-) } \\
\text { Cv100 IPM tool } \\
\text { POP3 Friesland } \\
\text { Schone kisten en } \\
\text { schoon } \\
\text { oppervlaktewater } \\
\text { (2018-2020) } \\
\text { POP3 Friesland } \\
\text { Agricorder TM } \\
\text { DNA veldtest voor } \\
\text { bacterieziekten in } \\
\text { aardappelen } \\
\text { (2017-2019) } \\
\text { POP3 Flevoland } \\
\text { Selectieve aanpak } \\
\text { Phytophthora } \\
\text { Pootgoed (2018- } \\
\text { 2021) } \\
\text { POP } 3 \text { Flevoland } \\
\text { Uitrol Duurzame } \\
\text { teelt Uien en Peen } \\
\text { (2018-2021) } \\
\text { POP3 Noord } \\
\text { Brabant } \\
\text { Automatisch } \\
\text { wieden praktijkrijp } \\
\text { (2017-2020) } \\
\text { POP3 Limburg } \\
\text { Agricorder sneltest } \\
\text { voor koprot in uien } \\
\text { (2018-2020) }\end{array}$ & $\begin{array}{l}\text { Diverse B2B projecten } \\
\text { toetsen } \\
\text { zuiveringsapparatuur }\end{array}$ \\
\hline
\end{tabular}




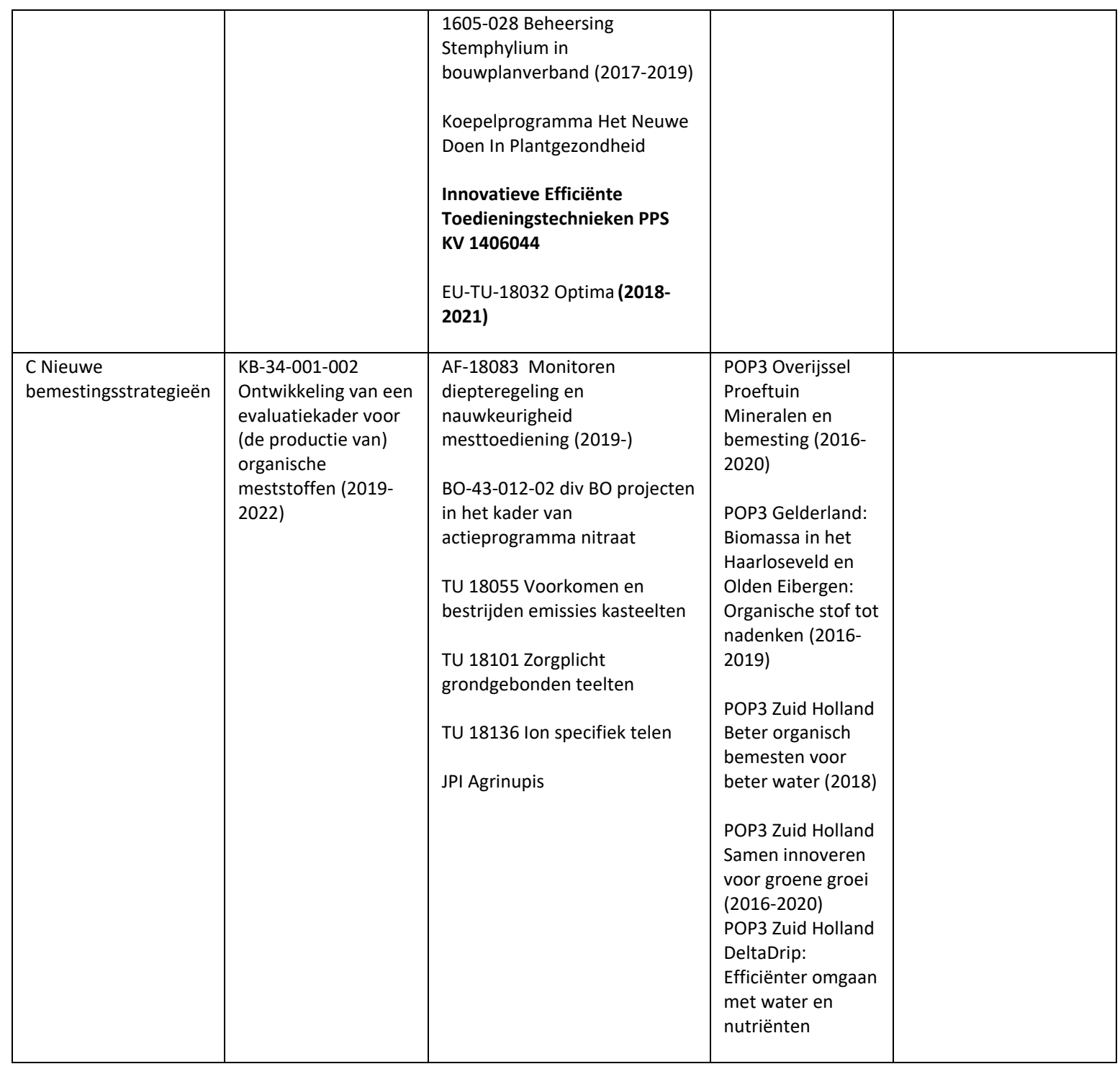


Tijdens de interactieve workshop op 9 mei 2019 met kennisinstellingen, overheden, landbouwbedrijfsleven, ketenpartijen, en betrokkenen bij het Deltaplan Biodiversiteit is in kaart gebracht wat de witte vlekken zijn voor de verschillende kennis- en innovatie opgaven. . De eerste versie van de omgevingsscan is getoetst in de workshop en aangepast naar aanleiding van de resultaten van de workshop.

Tijdens de workshop werd de integrale ontwikkeling van het totale weerbare, robuuste systeem door slim benutten van bodem, robuuste rassen, gewasdiversiteit in ruimte en tijd (mengteelt, rotatie), functionele agrobiodiversiteit, gewasbeschermingstechnieken, en bemesting, rekening houdend met plaatselijke omstandigheden als prioritair benoemd. Denk hierbij aan een plant die geschikt is voor teelt (veredeling) die past bij de omgeving in een bodem die gevoed wordt met meststoffen uit een zo kort mogelijke kringloop. Dat vraagt veredeling-bodem-teelt- mechanisatie en high tech - gewasbescherming-bemesting- integraal te beschouwen. Wat deze onderzoekslijn belangrijk maakt, zijn de kennisintegratie en de regionale samenwerking die nodig is om het systeem te laten functioneren en de kennis en inzichten die een ondernemer nodig heeft om dit uit te kunnen voeren, ook onder veranderende klimatologische omstandigheden.

Daarnaast werden de volgende kennis- en innovatieopgaven benoemd als prioritair en potentieel met hoge impact:

Ontwikkeling van robuuste rassen passend in de nieuwe teeltsystemen (bestand tegen klimaatverandering en andere (a)biotische stress);

Ontwikkeling van graslandvegetaties passend in de nieuwe teelsystemen (bestand tegen klimaatverandering en andere (a)biotische stress (bijvoorbeeld kruidenrijk grasland));

Ontwikkeling van een robuuste en weerbare bodem t.a.v. organische stof, bodemvruchtbaarheid, bodemweerbaarheid, bodemleven, efficiënt gebruik van nutriënten, beperken van (ondergrond)verdichting en een goede waterbuffering;

Ontwikkeling van nieuwe gewasbescherming als oplossing voor knelpunten in de nieuwe teeltsystemen (weerbare planten, weerbare teeltsystemen en geïntegreerde groene gewasbescherming en biocontrol voor open teelten en doorontwikkeling van biocontrolsystemen voor kasteelten (zowel micro als macro); Ontwikkeling van indicatoren voor biodiversiteit t.b.v. agrarische productie en natuur op verschillende schalen; Inzicht in en oplossingen voor mogelijke trade- offs tussen maatregelen gericht op klimaatadaptatie en mitigatie, en maatregelen gericht op beperking van emissies (nutriënten en gewasbeschermingsmiddelen) waardoor bedrijfsconcepten ontwikkeld kunnen worden waarmee telers aan de normen kan voldoen op al deze vlakken;

Fytosanitaire gezondheid en maatregelen om deze te kunnen garanderen; Detectietechnieken voor ziekten, plagen, onkruiden en beneficials.

Samenwerking plantaardige en dierlijke productie: productie van ruwvoer van eigen bodem met efficiënt landgebruik, goede kwaliteit van ruwvoer. Voer dat bijdraagt aan de beperking van emissies door vee, waarbij de relatie met kwalitatief goede bruikbare mest voor plantaardige sector voorop staat. Ontwikkeling van kruidenrijk grasland t.b.v. diergezondheid en biodiversiteit. Ontwikkeling van de geschikte rassen. Mest als een waardevol product en geen afvalproduct dat met kunstgrepen opgewaardeerd moet worden tot een product. Afstemming over andere vormen van landgebruik tussen veehouderij en akkerbouw.

Nieuwe bemestingsstrategieen: om de emissie van nutriënten in 2027 sterk teruggedrongen te hebben is voor de kasteelt op substraat sterk ingezet op hergebruik van al het water dat binnen het bedrijf wordt gebruikt en het zuiveren van reststromen voordat ze worden afgevoerd. Om een dergelijk systeem in de praktijk over de volle breedte goed te 
laten functioneren moeten nog diverse kennisvragen beantwoord worden. Voor grondteelten in en buiten de kas liggen er vooral oplossingrichtingen in redesign van teeltsystemen (teelt de grond uit, hydrologische oplossingen) en verhogen nutrientenefficiency (precisiebemesting, sensoren, meetsystemen)

De gedetailleerde kennis-en innovatieopgaven behorend bij deze onderwerpen staan in onderstaande tabel weergegeven.

Tabel 2: Gedetailleerde kennis en innovatie opgaven per fase van het kennis- en innovatietraject.

\begin{tabular}{|c|c|c|c|c|}
\hline Onderwerp & $\begin{array}{l}\text { Onderzoeksfase } \\
\text { TRL 1-3 } \\
\text { (NWO, KNAW, EU, } \\
\text { Kennis-basis, } \\
\text { strategische } \\
\text { middelen etc.) }\end{array}$ & $\begin{array}{l}\text { Ontwikkelfase TRL 4-6 } \\
\text { (toegepast } \\
\text { onderzoek, } \\
\text { beleidsondersteunen } \\
\text { d onderzoek) }\end{array}$ & $\begin{array}{l}\text { Demonstratiefase TRL 7-9 } \\
\text { (MIT, POP, fieldlabs, etc.) }\end{array}$ & $\begin{array}{l}\text { Implementatiefase } \\
\text { (subsidies, investeringen, } \\
\text { regelgeving, kennisverspreiding, } \\
\text { netwerken, campagnes etc.) }\end{array}$ \\
\hline \multicolumn{5}{|c|}{ Deelprogramma 1: Slim inrichten van weerbare plantaardige productie systemen } \\
\hline $\begin{array}{l}\text { A. Het ontwerp } \\
\text { van het totale } \\
\text { weerbare, } \\
\text { robuuste, } \\
\text { klimaatadaptieve } \\
\text { systeem, door } \\
\text { slim benutten } \\
\text { van bodem, } \\
\text { robuuste rassen, } \\
\text { functionele } \\
\text { agrobiodiversitei } \\
\text { t, } \\
\text { gewasdiversiteit } \\
\text { in ruimte en tijd, } \\
\text { gewasbeschermi } \\
\text { ng, en } \\
\text { bemesting, } \\
\text { rekening } \\
\text { houdend met } \\
\text { plaatselijke } \\
\text { omstandigheden } \\
\text {. }\end{array}$ & 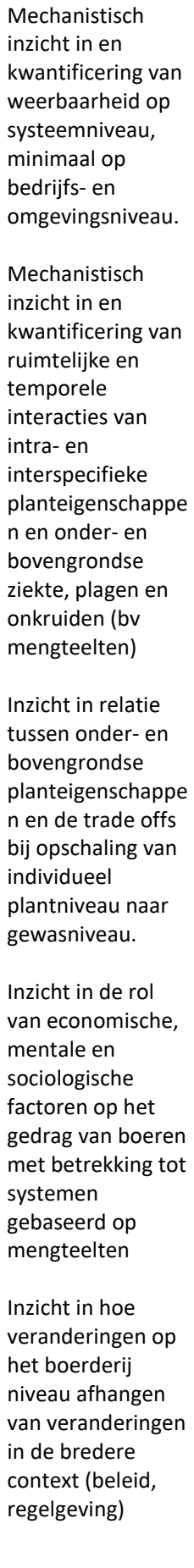 & 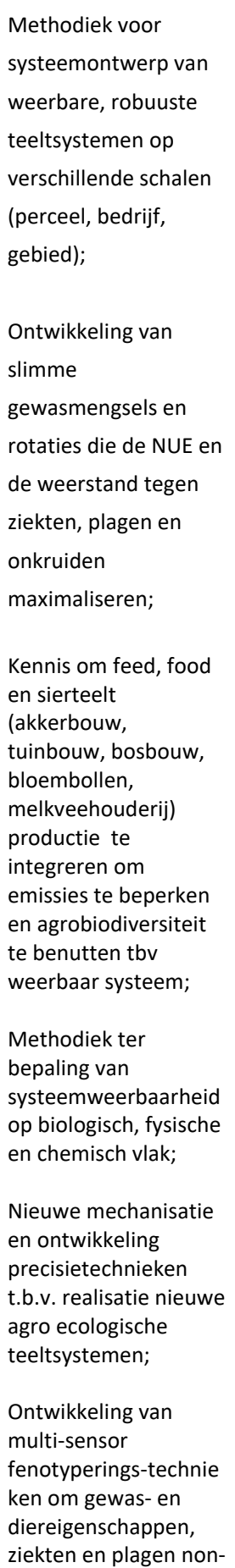 & 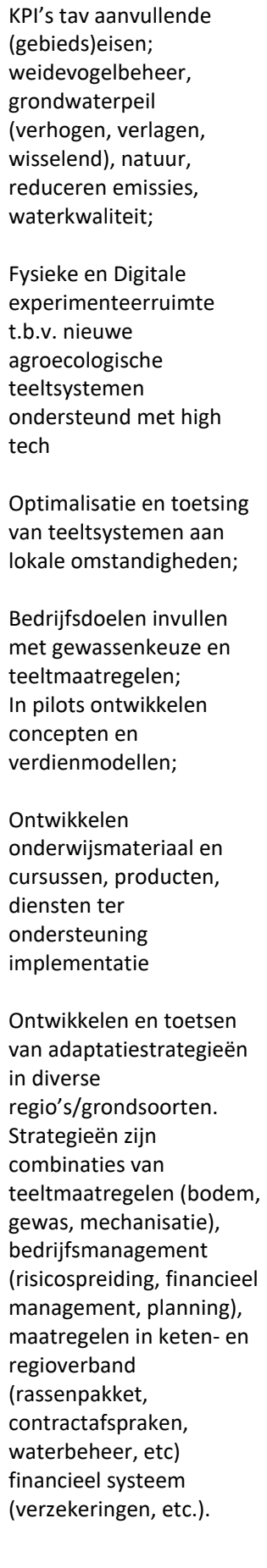 & 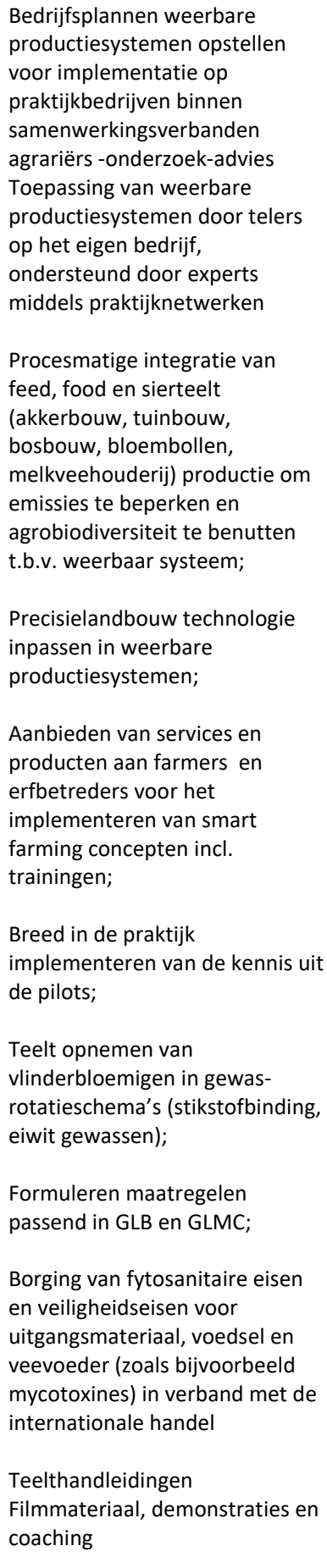 \\
\hline
\end{tabular}




\begin{tabular}{|c|c|c|c|c|}
\hline & 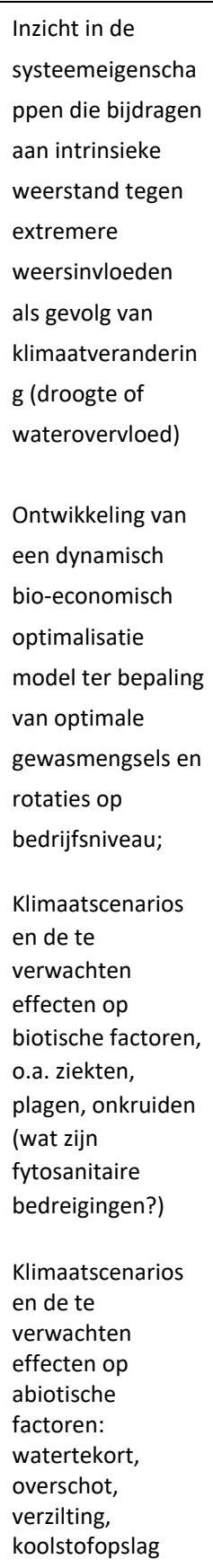 & 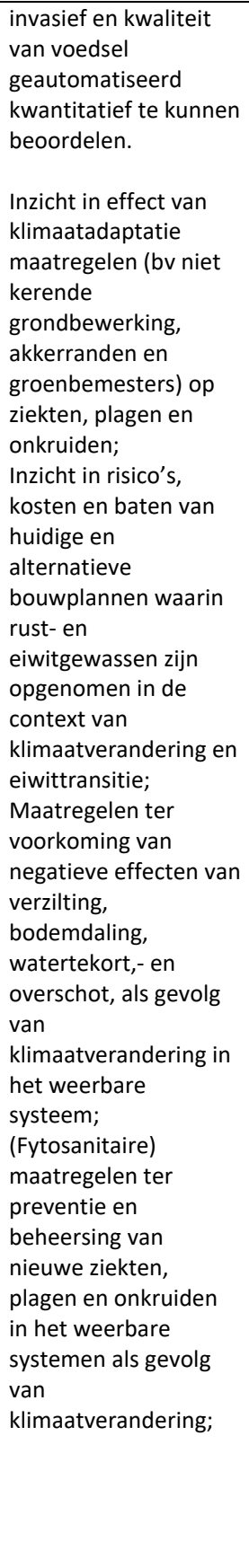 & & $\begin{array}{l}\text { Data tbv opnemen technieken in } \\
\text { investeringsregelingen } \\
\text { MIA/VAMIL }\end{array}$ \\
\hline $\begin{array}{l}\text { B Duurzaam } \\
\text { bodembeheer }\end{array}$ & $\begin{array}{l}\text { Fundamenteel } \\
\text { inzicht in de relatie } \\
\text { tussen organische } \\
\text { stof, } \\
\text { bodemvruchtbaar } \\
\text { heid, } \\
\text { bodemweerbaarh } \\
\text { eid, bodemleven, } \\
\text { bodemverdichting, } \\
\text { waterbuffering en } \\
\text { nutriënten, } \\
\text { vastlegging van de } \\
\text { kennis in een } \\
\text { model; } \\
\text { Integrale } \\
\text { beschrijving } \\
\text { (model) van } \\
\text { bodem waarin } \\
\text { cruciale } \\
\text { eigenschappen } \\
\text { (biologisch, } \\
\text { chemische en }\end{array}$ & $\begin{array}{l}\text { Kennisontwikkeling } \\
\text { over relatie tussen } \\
\text { maatregelen, } \\
\text { bodemkwaliteit en } \\
\text { ecosysteemdiensten } \\
\text { integraal over alle } \\
\text { bodemaspecten, met } \\
\text { focus op maatregelen } \\
\text { met effect op } \\
\text { bodembiologie en } \\
\text { effect van } \\
\text { bodembiologie op } \\
\text { ecosysteemdiensten } \\
\text { Methodiek ter } \\
\text { bepaling van } \\
\text { bodemweerbaarheid } \\
\text { Robuuste systematiek } \\
\text { voor het meten van }\end{array}$ & $\begin{array}{l}\text { Toetsing van effectieve } \\
\text { maatregelen gericht op } \\
\text { bodemkwaliteit en } \\
\text { ecosysteemdiensten op } \\
\text { proefbedrijven } \\
\text { Ontwikkeling van een } \\
\text { robuuste eenduidige } \\
\text { systematiek als basis voor } \\
\text { verwaarding van goede } \\
\text { bodemkwaliteit bij o.a. } \\
\text { grondtransacties }\end{array}$ & $\begin{array}{l}\text { Verkenning van de } \\
\text { inpasbaarheid van een robuuste } \\
\text { eenduidige systematiek als basis } \\
\text { voor verwaarding van goede } \\
\text { bodemkwaliteit bij o.a. } \\
\text { grondtransacties } \\
\text { Kennisoverdracht over effectieve } \\
\text { maatregelen gericht op } \\
\text { duurzaam bodembeheer middels } \\
\text { praktijknetwerken, onderwijs; } \\
\text { Opstellen van een } \\
\text { bodemkwaliteitsplan voor } \\
\text { bedrijfs- en perceelsniveau; } \\
\text { Kennisoverdracht over effectieve } \\
\text { maatregelen gericht op } \\
\text { duurzaam bodembeheer middels } \\
\text { praktijknetwerken, onderwijs; } \\
\text { Maatregelen ter inbedding van } \\
\text { pachtgronden in de } \\
\text { bedrijfsvoering; }\end{array}$ \\
\hline
\end{tabular}




\begin{tabular}{|c|c|c|c|c|}
\hline & $\begin{array}{l}\text { fysisch) } \\
\text { geïntegreerd } \\
\text { beschreven staan, } \\
\text { als middel om } \\
\text { verbeteringen te } \\
\text { modelleren en } \\
\text { implementeren; } \\
\text { Methodieken ter } \\
\text { bepaling van de } \\
\text { kwaliteit van de } \\
\text { bodembiologie. } \\
\text { Ontwikkeling van } \\
\text { technieken als } \\
\text { metagenomics, } \\
\text { bioinformatics; }\end{array}$ & $\begin{array}{l}\text { integrale } \\
\text { bodemkwaliteit } \\
\text { Kennis over de rol van } \\
\text { organische stof uit } \\
\text { verschillende bronnen } \\
\text { op de weerbaarheid } \\
\text { van het systeem } \\
\text { Ontwikkeling van } \\
\text { maatregelen om de } \\
\text { juiste } \\
\text { bodembiologische } \\
\text { samenstelling te } \\
\text { bevorderen: } \\
\text { (organische) } \\
\text { bemesting, compost, } \\
\text { groenbemesters, } \\
\text { grondbewerking, } \\
\text { gewasresten, } \\
\text { biostimulanten, } \\
\text { biological control } \\
\text { agents }\end{array}$ & & $\begin{array}{l}\text { Ketenafspraken over bodem - } \\
\text { kwaliteit en vergoeding } \\
\text { daarvoor; }\end{array}$ \\
\hline $\begin{array}{l}\text { C Robuuste } \\
\text { Rassen } \\
\text { Deze lijn sluit } \\
\text { aan bij de } \\
\text { sleuteltechnologi } \\
\text { e biotechnologie } \\
\text { en veredeling }\end{array}$ & $\begin{array}{l}\text { Kennis van het } \\
\text { pathogeen of } \\
\text { plaagorganisme. } \\
\text { Identificeren van } \\
\text { kruisbare bronnen } \\
\text { van } \\
\text { resistentie/toleran } \\
\text { tie. } \\
\text { Ophelderen van } \\
\text { onder-liggende } \\
\text { mechanismen of } \\
\text { pathways. } \\
\text { Onderzoeken } \\
\text { welke } \\
\text { onderliggende } \\
\text { genen en } \\
\text { pathways } \\
\text { betrokken zijn bij } \\
\text { NUE; } \\
\text { Onderzoek naar de } \\
\text { potentie van het } \\
\text { zaadmicrobioom } \\
\text { en biologicals voor } \\
\text { gezond zaaizaad } \\
\text { onafhankelijk van } \\
\text { chemische } \\
\text { gewasbeschermin } \\
\text { g. } \\
\text { Fundamenteel } \\
\text { fysiologisch } \\
\text { onderzoek gericht } \\
\text { op dessicate- } \\
\text { kieming. }\end{array}$ & 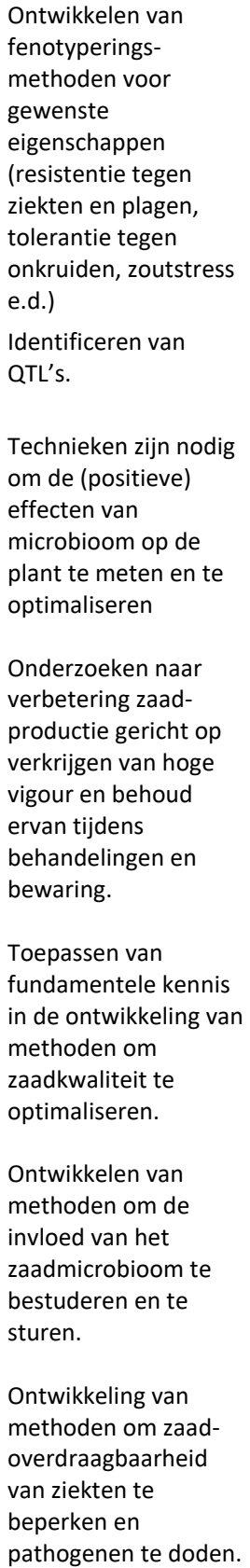 & 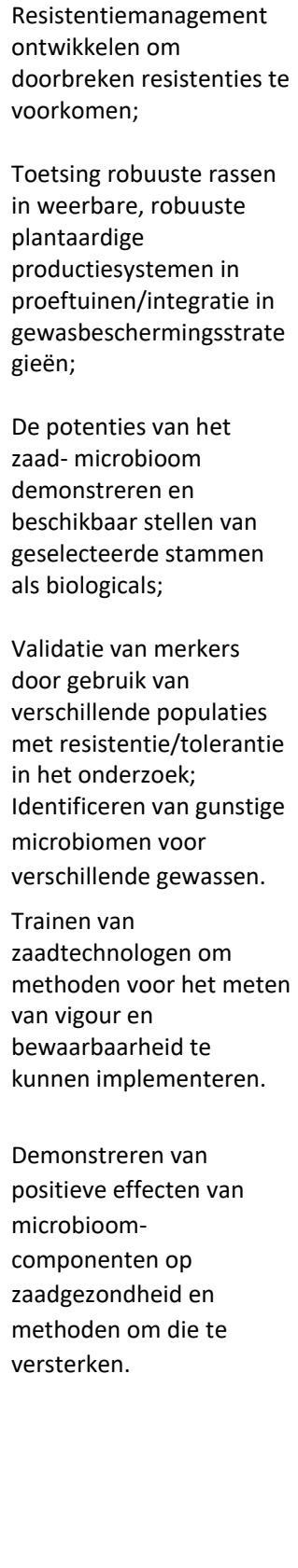 & $\begin{array}{l}\text { Toepassing bij } \\
\text { veredelingsbedrijven, } \\
\text { zaadproducenten, } \\
\text { zaadtechnologie bedrijven } \\
\text { Inpasbaarheid van rassen op } \\
\text { boerenbedrijven in weerbare } \\
\text { productiesystemen, inclusief } \\
\text { afspraken } \\
\text { resistentiemanagement; } \\
\text { Passende wet- en regelgeving } \\
\text { en/of experimenteerruimte om } \\
\text { nieuwe veredelingstechnieken } \\
\text { (bijvoorbeeld CRISPR/Cas) te } \\
\text { kunnen toepassen; } \\
\text { Colleges, cursussen, workshops } \\
\text { over robuuste rassen } \\
\text { Gebruik van merkers voor QTLs } \\
\text { in veredelings-programma's door } \\
\text { bedrijven. } \\
\text { Inkruisen van eigenschappen in } \\
\text { cultuurmateriaal. }\end{array}$ \\
\hline $\begin{array}{l}\text { D Functionele } \\
\text { agrobiodiversitei } \\
\mathrm{t}\end{array}$ & $\begin{array}{l}\text { Fundamenteel } \\
\text { inzicht in de relatie } \\
\text { tussen functionele }\end{array}$ & $\begin{array}{l}\text { Ontwerp van nieuwe } \\
\text { teelten en } \\
\text { teeltsystemen of }\end{array}$ & $\begin{array}{l}\text { Toetsing van maatregelen } \\
\text { ter bevordering van } \\
\text { agrobiodiverse }\end{array}$ & $\begin{array}{l}\text { Inzet van en stimuleren van } \\
\text { maatregelen ter bevorderen van }\end{array}$ \\
\hline
\end{tabular}




\begin{tabular}{|c|c|c|c|c|}
\hline $\begin{array}{l}\text { Deze lijn sluit } \\
\text { aan bij A4, maar } \\
\text { is meer gericht } \\
\text { op } \\
\text { productiedoelein } \\
\text { den }\end{array}$ & $\begin{array}{l}\text { groepen aan } \\
\text { productie } \\
\text { doeleinden op } \\
\text { plant, perceels-, } \\
\text { bedrijfs- en } \\
\text { regionaal niveau; } \\
\text { Inzicht in plant- } \\
\text { eigenschap } \\
\text { combinaties die de } \\
\text { efficiëntie van } \\
\text { natuurlijke } \\
\text { vijanden } \\
\text { maximaliseren; }\end{array}$ & $\begin{array}{l}\text { bouwstenen daartoe } \\
\text { gericht op de creatie } \\
\text { en benutting van } \\
\text { biodiversiteit voor de } \\
\text { primaire productie; } \\
\text { Ontwikkeling van } \\
\text { maatregelen ter } \\
\text { bevordering van } \\
\text { functionele } \\
\text { agrobiodiversiteit; }\end{array}$ & $\begin{array}{l}\text { teeltsystemen op } \\
\text { proefbedrijven; } \\
\text { Inzicht in trade offs met } \\
\text { onder- en bovengrondse } \\
\text { ziekten, plagen en } \\
\text { onkruiden; }\end{array}$ & $\begin{array}{l}\text { de functionele agrobiodiversiteit } \\
\text { op praktijkbedrijven; } \\
\text { Vertaling van maatregelen t.b.v. } \\
\text { biodiversiteit van bedrijfs-naar } \\
\text { gebiedsniveau. }\end{array}$ \\
\hline $\begin{array}{l}\text { E Ondersteunen } \\
\text { van } \\
\text { samenwerking } \\
\text { tussen de } \\
\text { sectoren }\end{array}$ & $\begin{array}{l}\text { Kwantificering van } \\
\text { de klimaateffecten } \\
\text { door teelt van } \\
\text { eiwit en } \\
\text { rustgewassen } \\
\text { Verkenning } \\
\text { grondgebondenhe } \\
\text { id intensieve } \\
\text { veehouderij } \\
\text { (varkens, } \\
\text { pluimvee) } \\
\text { Verhoging van } \\
\text { nutrientenefficient } \\
\text { ie in de teelt van } \\
\text { ruwvoergewassen }\end{array}$ & $\begin{array}{l}\text { Ontwikkelen } \\
\text { maatregelen ter } \\
\text { optimalisatie van } \\
\text { ruwvoederproductie } \\
\text { per oppervlakte } \\
\text { eenheid }\end{array}$ & & $\begin{array}{l}\text { Akkerbouw-Veehouderij } \\
\text { praktijknetwerken op het gebied } \\
\text { van duurzaam bodembeheer, } \\
\text { gezonde vruchtwisseling, } \\
\text { duurzame bemesting, duurzame } \\
\text { veevoerproductie } \\
\text { GLB maatregelen ter } \\
\text { bevordering van teelt van eiwit- } \\
\text { en rustgewassen }\end{array}$ \\
\hline \multicolumn{5}{|c|}{ Deelprogramma 2 Slim bijsturen van weerbare plantaardige productie systemen } \\
\hline $\begin{array}{l}\text { A Monitoring- en } \\
\text { detectie } \\
\text { systemen } \\
\text { Deze lijn sluit } \\
\text { aan bij de } \\
\text { sleuteltechnologi } \\
\text { e high tech }\end{array}$ & & $\begin{array}{l}\text { Ontwikkeling van } \\
\text { monitorings- en } \\
\text { detectiemethodieken } \\
\text { van insecten, } \\
\text { schimmels, onkruiden, } \\
\text { bacteriën, nematoden } \\
\text { en hun vectoren; } \\
\text { Inzicht in de } \\
\text { schaderelaties tussen } \\
\text { aantasting en } \\
\text { gewasschade; } \\
\text { Integratie van } \\
\text { sensordata met } \\
\text { gewasbeschermings-, } \\
\text { bemestingsstrategieen } \\
\text { en } \\
\text { toedieningstechnieken } \\
\text { tbv precisielandbouw }\end{array}$ & $\begin{array}{l}\text { Toetsing van (precieze) } \\
\text { monitorings- en } \\
\text { detectiemethodieken in } \\
\text { weerbare teeltsystemen; } \\
\text { Precisietoedieningen/toep } \\
\text { assingen ondersteund } \\
\text { door sensing/geodata } \\
\text { platform en faciliterende } \\
\text { (big)data analyse }\end{array}$ & $\begin{array}{l}\text { Colleges, cursussen, workshops, } \\
\text { demonstraties over monitorings- } \\
\text { en detectietechnieken; } \\
\text { Fysieke en digitale } \\
\text { experimenteerruimte en } \\
\text { ondersteuning voor partijen die } \\
\text { met elkaar willen samenwerken } \\
\text { voor nieuwe data-gedreven } \\
\text { oplossingen; } \\
\text { Vertaling van (big) data naar } \\
\text { management informatie voor } \\
\text { agrariers en adviseurs }\end{array}$ \\
\hline $\begin{array}{l}\text { B Nieuwe } \\
\text { gewasbeschermi } \\
\text { ng strategieën }\end{array}$ & $\begin{array}{l}\text { Inzicht in relatie } \\
\text { tussen } \\
\text { microbioom en } \\
\text { intrinsieke/geïndu } \\
\text { ceerde } \\
\text { weerbaarheid van } \\
\text { de plant; } \\
\text { Kennis over de } \\
\text { levenscycli van } \\
\text { bodempathogene } \\
\text { n en -plagen ten } \\
\text { bate van DSS; }\end{array}$ & $\begin{array}{l}\text { Ontwikkeling van } \\
\text { bestrijdingsmethoden } \\
\text { op basis van biologie: } \\
\text { slim inzetten insecten } \\
\text { en micro-organismen, } \\
\text { bovenop het inzetten } \\
\text { van vruchtwisseling, } \\
\text { gewasdiversificatie en } \\
\text { gebiedsbiodiversiteit; } \\
\text { Ontwikkeling van } \\
\text { biocontrol agents, } \\
\text { zowel micro als } \\
\text { macro; } \\
\text { Inzicht in de mogelijke } \\
\text { effecten van residuen } \\
\text { van biocontrol agents } \\
\text { in de keten voor } \\
\text { volksgezondheid en } \\
\text { fytosanitaire keten; } \\
\text { Ontwikkeling van } \\
\text { biostimulanten; }\end{array}$ & $\begin{array}{l}\text { Toetsing van } \\
\text { gewasbeschermingsstrate } \\
\text { gieen in weerbare } \\
\text { teeltsystemen op } \\
\text { proefbedrijven; } \\
\text { Toetsing van } \\
\text { geïntegreerde } \\
\text { gewasbescherming, } \\
\text { inclusief } \\
\text { precisietechnieken; } \\
\text { Toetsing biocontrol } \\
\text { agents, biostimulanten en } \\
\text { drempelwaardes ten } \\
\text { behoeve van bestrijding } \\
\text { op praktijkschaal; } \\
\text { Maatregelen ter preventie } \\
\text { van residuen van } \\
\text { biocontrol agents in de } \\
\text { keten voor } \\
\text { volksgezondheid en } \\
\text { fytosanitaire keten; }\end{array}$ & $\begin{array}{l}\text { Opstellen van geïntegreerde } \\
\text { gewasbeschermingstrategieen } \\
\text { passend in weerbare } \\
\text { productiesystemen door telers } \\
\text { op het eigen bedrijf, } \\
\text { ondersteund door experts } \\
\text { middels } \\
\text { samenwerkingsverbanden } \\
\text { onderzoek-praktijk; } \\
\text { Verzekering voor niet preventief } \\
\text { inzetten } \\
\text { gewasbeschermingsmiddelen } \\
\text { tegen ziekten en plagen die } \\
\text { incidenteel voorkomen (bv } \\
\text { maïsstengelboorder); } \\
\text { Advisering gericht op inrichten } \\
\text { van teeltsysteem ter preventie } \\
\text { van ziekten, plagen en } \\
\text { onkruiden; }\end{array}$ \\
\hline
\end{tabular}




\begin{tabular}{|c|c|c|c|}
\hline & $\begin{array}{l}\text { Ontwikkeling van } \\
\text { drempelwaardes en } \\
\text { bestrijdingsdrempels } \\
\text { ten behoeve van de } \\
\text { precieze inzet van } \\
\text { bestrijding van } \\
\text { ziekten, plagen en } \\
\text { onkruiden; } \\
\text { Ontwikkeling van } \\
\text { maatregelen gericht } \\
\text { op beheer (kwaliteit } \\
\text { en kwantiteit) van } \\
\text { organische stof tbv } \\
\text { minimale emissies van } \\
\text { gewasbeschermingsmi } \\
\text { ddelen; } \\
\text { Onderzoek naar breed } \\
\text { inzetbare predatoren } \\
\text { voor iedere teelt als } \\
\text { basis voor de Standing } \\
\text { Army. Dit geldt voor } \\
\text { een breed scala aan } \\
\text { ziekten en plagen en } \\
\text { voor alle } \\
\text { (glastuinbouw)gewass } \\
\text { en }\end{array}$ & & \\
\hline $\begin{array}{l}\text { C Nieuwe } \\
\text { bemestingsstrat } \\
\text { egieën } \\
\text { Deze lijn sluit } \\
\text { aan bij A1, maar } \\
\text { is meer } \\
\text { ingestoken } \\
\text { vanuit de teelt. } \\
\text { In Missie A1 } \\
\text { wordt gericht op } \\
\text { nutrienten uit } \\
\text { reststromen en } \\
\text { verwarding van } \\
\text { mest }\end{array}$ & $\begin{array}{l}\text { Sensorsystemen voor } \\
\text { vroegtijdige kosten } \\
\text { effectieve detectie van } \\
\text { water en } \\
\text { nutrientenstress bij } \\
\text { planten in open } \\
\text { teelten } \\
\text { State of the art } \\
\text { adviezen rond } \\
\text { bemesting en irrigatie } \\
\text { en efficiëntere } \\
\text { bemestings- en } \\
\text { irrigatietechnieken } \\
\text { Welke organische } \\
\text { meststoffen en welke } \\
\text { beheersmaatregelen } \\
\text { zorgen voor een } \\
\text { verhoging van het } \\
\text { organisch stofgehalte } \\
\text { zonder emissie van } \\
\text { nutriënten naar } \\
\text { oppervlakte water en } \\
\text { grondwater en via } \\
\text { lachgas of } \\
\text { ammoniakemissie } \\
\text { naar de lucht } \\
\text { Doorontwikkelen van } \\
\text { innovatieve } \\
\text { teeltsystemen los van } \\
\text { de ondergrond voor } \\
\text { gewassen die } \\
\text { momenteel in de } \\
\text { grond worden geteeld } \\
\text { Welke reststromen } \\
\text { zijn inpasbaar in een } \\
\text { weerbaar } \\
\text { productiesysteem }\end{array}$ & $\begin{array}{l}\text { Demonstratie en } \\
\text { doorontwikkeling van } \\
\text { nieuwe } \\
\text { bemestingssystemen op } \\
\text { demonstratiebedrijven } \\
\text { Ontwikkelen van low-tech } \\
\text { substraat systemen } \\
\text { Ontwikkelen van } \\
\text { implementatiestrategien }\end{array}$ & $\begin{array}{l}\text { Ontwikkeling van specifieke } \\
\text { normen voor de verschillende } \\
\text { regio's/grondsoorten } \\
\text { GLMC: gebruik van het } \\
\text { landbouwbedrijfsduurzaamheids } \\
\text { instrument voor nutriënten }\end{array}$ \\
\hline
\end{tabular}


Een sterke wisselwerking tussen Onderzoek, Ontwikkeling, Demonstratie en Implementatie is voor deze missie van essentieel belang, evenals samenwerking tussen verschillende sectoren op het gebied van oa benutting meststoffen en landgebruik door het stimuleren en faciliteren van leerprocessen in de vorm van praktijknetwerken, demonstratieactiviteiten, onderwijs en advies gericht op alle betrokken stakeholders.

Innovaties kunnen opgepakt worden in fundamentele onderzoeksprojecten (TRL1-3), in toegepast onderzoek in ontwikkelingsprojecten (TRL4-6), in participerend onderzoek en demonstratie (TRL 7-9). Deze worden ondersteund door investeringen, regelgeving, kennisverspreiding, netwerken en subsidies om te komen tot implementatie. In transitie projecten waarin de stakeholders betrokken zijn wordt de benodigde informatie verzameld om de ondersteunende maatregelen zoals investeringen, regelgeving, kennisverspreiding, netwerken en subsidies te kunnen ontwikkelen en implementeren.

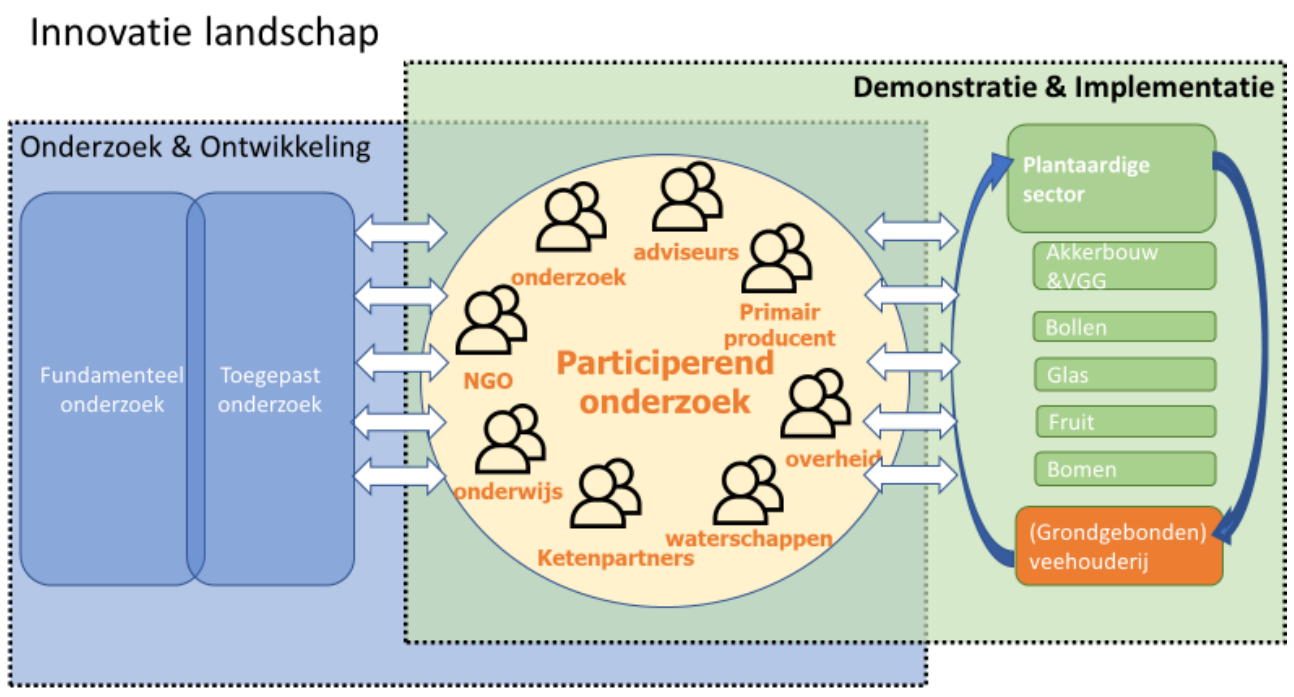

Figuur 3 Een sterke wisselwerking tussen Onderzoek, Ontwikkeling, Demonstratie en Implementatie is voor deze MMIP van essentieel belang, evenals samenwerking tussen verschillende sectoren op het gebied van oa benutting meststoffen, landgebruik en het ontwikkelen van nieuwe verdienmodellen.

Kennis en innovatie opgaven die opgepakt kunnen worden in projecten op TRL niveau 4-9 hebben het meest perspectief op een publiek-private aanpak.

Kennis en innovatie opgaven met een meer fundamenteel karakter (TRL 1-3), en opgaven gericht op integratie van agronomie, ecologie en technologie hebben beperkt zicht op financiering via PPS constructies. In beide gevallen ontbreekt een direct economisch belang van private partners, en is er eerder sprake van een groter publiek (sectoroverstijgend) belang.

De topsectoren Agri\& Food en Tuinbouw en Uitgangsmaterialen zijn belangrijke stimuli voor de vorming van consortia tussen kennisinstellingen en bedrijfsleven voor de het formuleren en uitvoeren van onderzoeksprojecten. De afgelopen jaren was de vraag om budget telkens groter dan het aantal projecten dat gehonoreerd kon worden nadat deze door de reviewcommissies als "goed" waren. Dit geeft heel duidelijk aan dat er vanuit het bedrijfsleven een grote wens is om samen te werken met kennisinstellingen.

Voor deze missie zijn partners vanuit de veredeling, gewasbescherming, bemesting, primaire sector, ketenpartijen, overheden, advisering, ngo's en techniek van belang voor de vorming 
van consortia. Al naar gelang het deelprogramma zijn verschillende consortia denkbaar op de genoemde deelprogramma's.

Potentiele partners (niet uitputtend): LTO, Plantum leden, leden van BO akkerbouw (o.a. Cosun, AVEBE, comite van graanhandelaren, van Iperen BV, Agrifirm BV, NAO, NAJK, NAV,VAVI), Club van 100, NFO, Artemis leden (Biobest, Vlamings, Hortipro, Valto, Bayer Crop Science, Ecostyle, Certis, Cebeco, Natural Biopol, Nufarm,Syngenta, Koppert, Handelsonderneming Klep,Vos Cappelle, BASF, Arysta, Pronafit, Nijhof, Pireco, Plant Research, DENKA, Royal Brinkman, Mertens, PHC, Entocare,DCM), Nefyto leden, waterschappen, provincies, KAVB, Leden van Agrodis (ADAgro B.V.,Agrea, Agriant B.V., Agrowin, AgruniekRijnvallei, Alliance, Benfried B.V. ,P. Bestebreurtje, Ten Brinke Holding B.V., Brinkman Agro, CAV Agrotheek, Cebeco Agrochemie, CZAV Coöp. Zuidelijke Aan- en Verkoopvereniging, Forfarmers Hendrix B.V., GMN, Alb. Groot B.V. , Holland Fyto U.A., Horticoop, Huntjens, Jabaay B.V., Handelsonderneming G.J. Klep, P.G. Kusters Land- en Tuinbouwbenodigdheden B.V., H. van de Maarl, Mertens, Van Overloop gewasbeschermingsmiddelen B.V., Profytodsd, Telermaat, Gewasbeschermingsmiddelenhandel Theunisse B.V., Handelsonderneming Vlamings B.V., Fa. Joh. Vos Capelle B.V., R. van Wesemael, Willems Balgoy VOF), WPA-Robertus zeker \& vast B.V., Waterschappen, Provincies, Stichting Weidegang, leden van de Nederlandse Vereniging Diervoederindustrie (NEVEDI), Diervoederfabrikanten, Bancaire instellingen, Accountants, Zuivel verwerkende industrie, Nederlandse Zuivelorganisatie (NZO), Cumela, NGO's bijvoorbeeld Natuurmonumenten, Vogelbescherming, BLHB (Organisatie voor pachters, eigenaren, grondgebruikers en erfpachters), Groenten en Fruit Huis, John Deere, Rometron, Agrometius, Eurofins AGRO, Yara Benelux B.V., Barenbrug Holland B.V., Avantes and Tec5, Tolsma Techniek Emmeloord B.V, Eijkelkamp Soil \& Water B.V., VAA ICT Consultancy, BioDAC, KPN B.V, Kverneland Group Mechatronics B.V. (Kverneland Group), Kubota Corporation, NEO B.V, AeroVision B.V., Loonbedrijf Thijssen, Agrovision BV, Agrifac, Drone4Agro, Agro Intelli, Protonic Holland, Groothandel, Supermarkten. 


\section{$6 \quad$ Programmeringsadvies}

Om te komen tot de ontwikkeling van het totale weerbare teeltsysteem is een integrale aanpak nodig op basis van het slim benutten van bodem, robuuste rassen, gewasdiversiteit in ruimte en tijd, functionele agrobiodiversiteit, en het slim ingrijpen met gewasbeschermings-en bemestingstechnieken rekening houdend met de plaatselijke omstandigheden.

Naast de integrale systeemaanpak is het advies te investeren in fundamenteel onderzoek, toegepast onderzoek via ontwikkelingsprojecten en via participerend onderzoek, demonstratie en implementatie via de volgende twee lijnen:

1. Slim inrichten:

- Ontwikkeling van robuuste en weerbare rassen passend in de nieuwe teeltsystemen (bestand tegen klimaatverandering en andere (a)biotische stress).. Een uitgebreide beschrijving van benodigde technieken staan beschreven in de programmeringsstudie uitgangsmateriaal en veredeling;

- Ontwikkeling van een robuuste en weerbare bodem tav organische stof, bodemvruchtbaarheid, bodemweerbaarheid, bodemleven, efficiënt gebruik van nutriënten, beperken van (ondergrond)verdichting en een goede waterbuffering. Bodemprocessen verlopen over meerdere jaren, daarmee zijn langjarige programma's wenselijk;

- Ontwikkeling indicatoren voor biodiversiteit t.b.v. agrarische productie en natuur op verschillende schalen;

\section{Slim bijsturen:}

- Ontwikkeling van nieuwe gewasbescherming als oplossing voor knelpunten in de nieuwe teeltsystemen (weerbare planten, weerbare teeltsystemen en geïntegreerde groene gewasbescherming en biocontrol voor open teelten (zowel micro als macro);

- Ontwikkeling van drempelwaardes, bestrijdingsdrempels en detectietechnieken ten behoeve van de precieze inzet van bestrijding van ziekten, plagen en onkruiden;

- Nieuwe bemestingsstrategieën met inzet van precisiebemesting en slim beheer en inzet van organische stof;

- Integratie van sensordata met gewasbeschermings- en bemestingsstrategieen en toedieningstechnieken t.b.v. precisielandbouw

Figuur 4 geeft een schematisch overzicht van de voorgestelde programmering.

Voor deze innovatielijnen geeft tabel 2 een overzicht van de gedetailleerde kennis en innovatie opgaven die passen bij deze lijnen in dit programma. Daarbij is het wenselijk dat fundamentele onderzoeksprojecten (TRL1-3), toegepast onderzoek in ontwikkelingsprojecten (TRL4-6) opgepakt worden met een perspectief op de iets langere termijn (5 jaar). De activiteiten gericht op het participerend onderzoek en demonstratie (TRL 7-9) en de investeringen, regelgeving, kennisverspreiding, netwerken en subsidies om te komen tot implementatie kunnen gericht worden op de kortere termijn (2 jaar). 


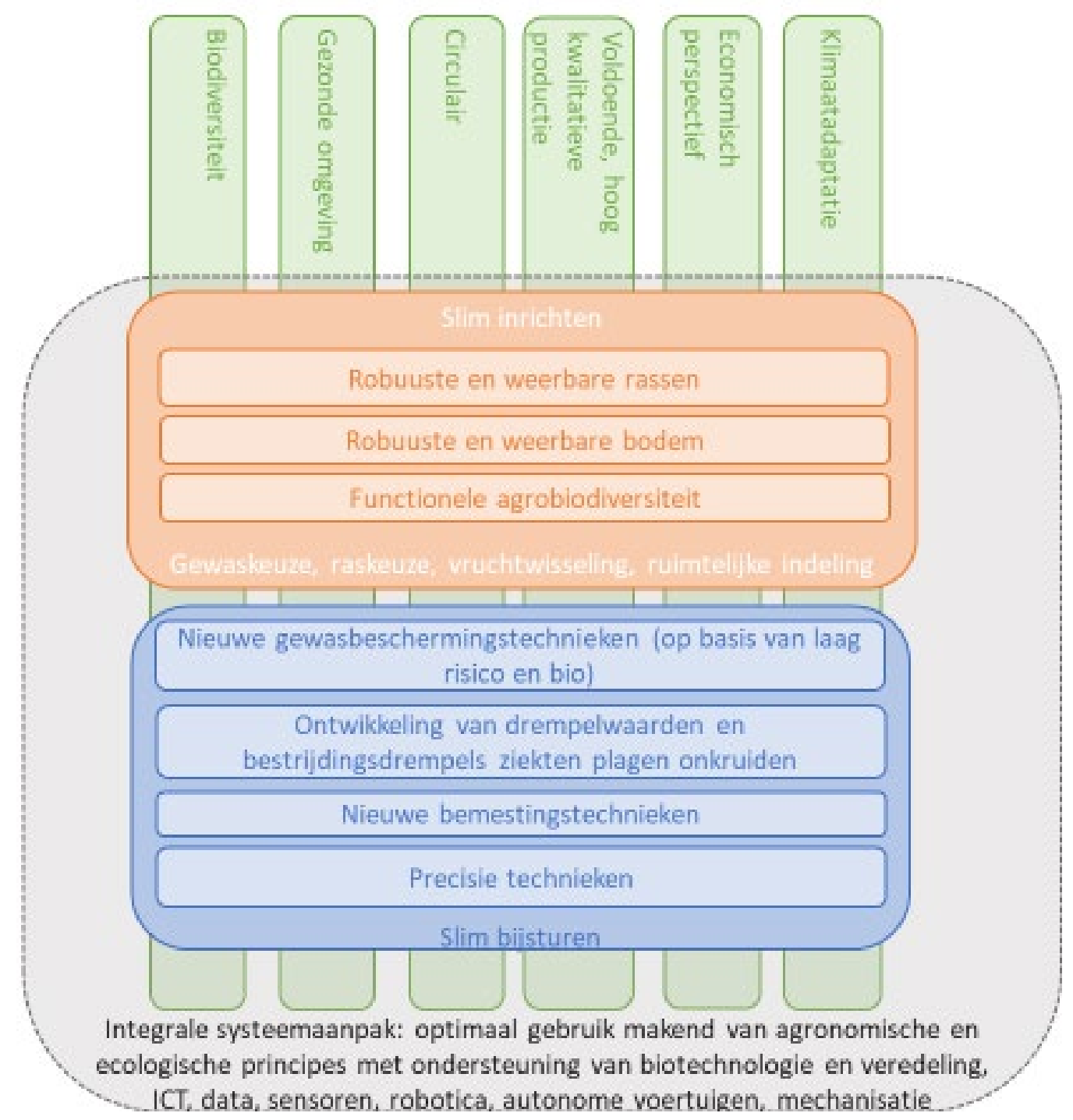

Figuur 4. Mogelijke programmering om te komen tot gezonde, robuuste bodem en teeltsystemen gebaseerd op agro-ecologie en zonder schadelijke emissies naar grond- en oppervlaktewater. Randvoorwaarden zijn klimaatadaptie, economisch perspectiefvol, voldoende kwalitatieve productie, circulair, bijdragend aan een gezonde omgeving en biodiversiteit. Programmalijnen betreffen: integrale systeemaanpak, slim inrichten (met als pijlers: robuuste en weerbare rassen, robuuste en weerbare bodem, functionele agrobiodiversiteit), en slim bijsturen (met als pijlers: nieuwe gewasbeschermingstechnieken, ontwikkeling van drempelwaarden en bestrijdingsdrempels, nieuwe bemestingstechnieken, Integratie van sensordata met gewasbeschermingsen bemestingsstrategieen en toedieningstechnieken t.b.v. precisielandbouw) 



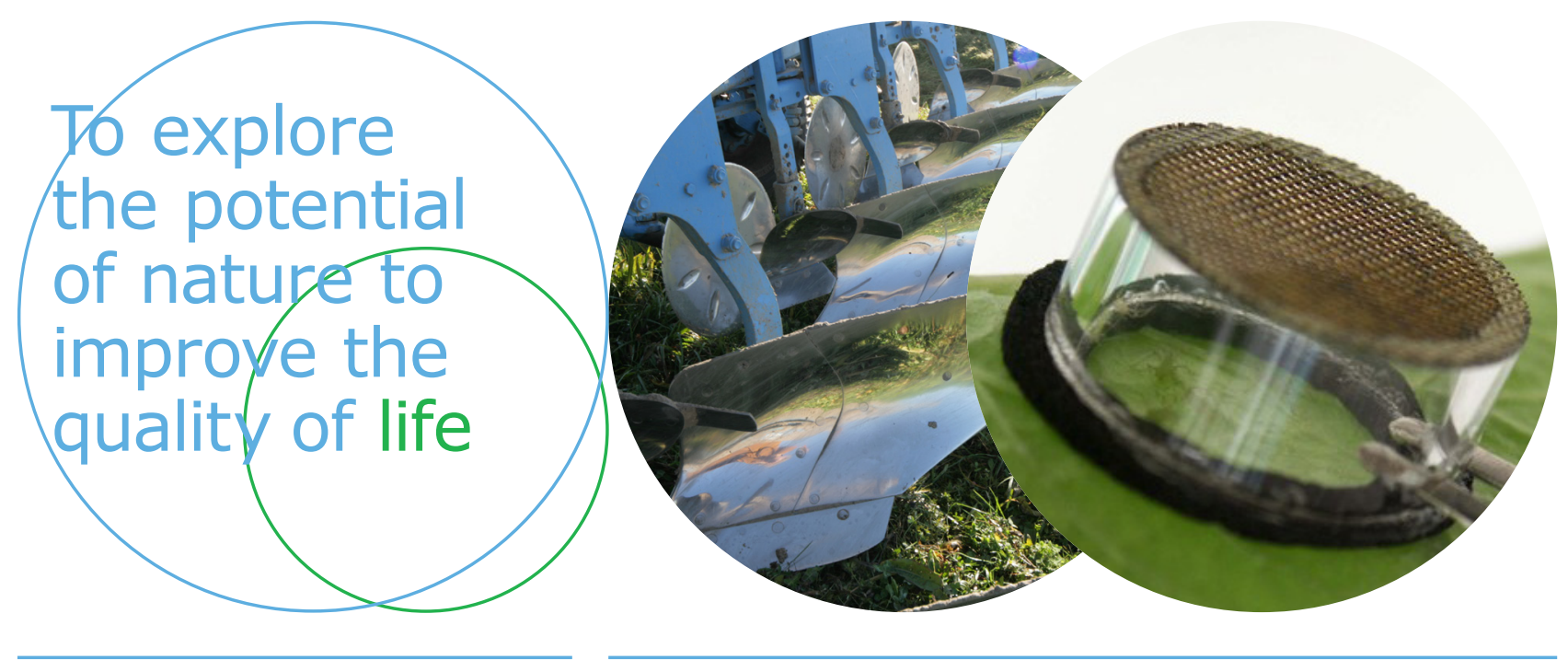

Correspondentie adres voor dit rapport: Wageningen University \& Research | Open Teelten

Edelhertweg 1

Postbus 430

8200 AK Lelystad

T (+31)320 291111

www.wur.nI/openteelten

Rapport WPR-814
De missie van Wageningen University \& Research is 'To explore the potential of nature to improve the quality of life'. Binnen Wageningen University \& Research bundelen 9 gespecialiseerde onderzoeksinstituten van stichting DLO en Wageningen University hun krachten om bij te dragen aan de oplossing van belangrijke vragen in het domein van gezonde voeding en leefomgeving. Met ongeveer 30 vestigingen, 6.000 medewerkers en 9.000 studenten behoort Wageningen University \& Research wereldwijd tot de aansprekende kennisinstellingen binnen haar domein.

De integrale benadering van de vraagstukken en de samenwerking tussen verschillende disciplines vormen het hart van de unieke Wageningen aanpak. 